Portland State University

PDXScholar

$4-1-2021$

\title{
Values of Young Adults in an Increasingly Secular World
}

Joseph Daniel Eichenlaub

Portland State University

Follow this and additional works at: https://pdxscholar.library.pdx.edu/open_access_etds

Part of the Other Religion Commons, and the Sociology Commons Let us know how access to this document benefits you.

\section{Recommended Citation}

Eichenlaub, Joseph Daniel, "Values of Young Adults in an Increasingly Secular World" (2021).

Dissertations and Theses. Paper 5679.

https://doi.org/10.15760/etd.7551

This Thesis is brought to you for free and open access. It has been accepted for inclusion in Dissertations and Theses by an authorized administrator of PDXScholar. Please contact us if we can make this document more accessible: pdxscholar@pdx.edu. 
Values of Young Adults in an Increasingly Secular World

by

Joseph Daniel Eichenlaub

A thesis submitted in partial fulfillment of the requirements for the degree of

Master of Science

in

Sociology

Thesis Committee:

Alex Stepick, Chair

Dara Shifrer

Daniel Jaffee

Portland State University

2021 


\begin{abstract}
This paper examines data from a religion and values survey entitled Young Adults and Religion in a Global Perspective (YARG) conducted in the spring of 2018. The data for this research comes from a sample of college undergraduates from diverse nations, Portland State being one of the sites sampled. This research takes a quantitative look at the data, as well as investigating three main research questions: Do the values of college age youth tend to be more individualistic, the less religious that they are? Do the irreligious still maintain moral values? And is irreligiosity related to a cosmopolitan-humanitarian outlook? This research finds that the overall sample is individualistic while still holding communal values, cosmopolitan humanitarianism is correlated with irreligiosity, and that young people who are not religious in a traditional manner maintain a moral compass in an increasingly secular world.
\end{abstract}




\section{Acknowledgements}

I would like to thank my committee Dr. Dara Shifrer, Dr. Dan Jaffee and my chair, Dr. Alex, Stepick; without whom none of this would have been possible. I am particularly thankful for Dr. Stepick's patience, guidance, vision, and generosity of his personal time I would never have been able to complete this research.

I would also like to thank my partner Kara Hannush, without her emotional and psychological help I could not have completed this work.

And, lastly for my father, who passed-on before he could see what the seed of curiosity he had planted had bloomed into. I love you; I hope you rest in peace and in the arms of loved ones. 


\section{Table of Contents}

Abstract

Acknowledgements $\quad$ ii

List of Tables $\quad$ iv

List of Figures $\quad$ V

Chapter One:

Introduction 1

Chapter Two:

Literature Review $\quad 4$

Chapter Three:

Methods

Chapter Four:

Values of Individuality, Religiosity and Cosmopolitanism/Humanitarianism,

$\begin{array}{ll}\text { Religion and Volunteering } & 44\end{array}$

Chapter Five:

The Data: Religion and Values Among College Aged Youth 51

Chapter Six:

Conclusions, Implications and Recommendations 67

$\begin{array}{ll}\text { References } & 75\end{array}$

Appendices

Appendix A: 19 Refined Schwartz Values from Refined Theory 80

Appendix B: YARG Survey $\quad 84$ 
$\underline{\text { List of Tables }}$

Table 4.1: "YARG Samples and Languages" 44

Table 4.2: "Basic Demographics of All Nations" 46

Table 4.3: "Religiosity of Self and Family by Nation" $\quad 48$

Table 4.4: "Low v. High Religiosity by Nation”

Table 5.1: "Mean Score for Each Schwartz" 55

Table. 5.2 "Descriptive Statistics: All Variables in Both Regressions" 58

Table 5.3 “Cosmopolitanism/Humanitarianism Predicted by Religiosity

Linear Regression” 61

Table 5.4 "Volunteering Regressed Against Religiosity" 66 


\section{$\underline{\text { List of Figures }}$}

Figure 2.1 "Gallup: Church Membership Among U.S. Adults

Figure 3.1: "Figure 3.1 "Schwartz Original Individual Values"

Figure 3.2: "Figure 3.2 Schwartz Values Expanded Version" 


\section{Chapter One}

\section{Introduction: The Problem}

"If there is no god, then anything is permitted" (Sartre 1956). So goes a famous quote by one of the most important existential philosophers of the $20^{\text {th }}$ century. Is Sartre correct? Are our secular times filled with the sense that we may act in any manner that we wish because there are no other-worldly consequences?

In an increasingly secular religious landscape, what are the values of young people? Are they individualistic or cosmopolitan humanitarianism? Do young people still exhibit traits of morality as evidenced by volunteering? Or does a measure of cosmopolitan humanitarianism exhibit young people's aptitude for acceptance of other cultures? Using a survey of university students from 13 countries, including a sample of Portland State University undergraduates, this thesis addresses these questions.

Sartre argues that if one does not believe in God moral chaos ensues. While, Maslow (1942), somewhat parallel to Sartre, maintains that in the wake of WWII individual values come to dominate over conservative ones, such as those promulgated by religion. And yet, other scholars such as Iannacone, Casssanova and Reitsma hold that religion has evolved from a group phenomenon to an individual one in which each person chooses their own faith and beliefs.

I develop a theoretical framework that centers on individual values. For example, researchers such as Maslow (1954) envision an increase in values of the self, especially in 
The United States following WWII. In the aftermath of the war with an outside threat diminished, a focus on individual values over group dynamics arose. Given that people in the West's basic needs are met, the ideology of consumerism easily develops in the postwar era, affecting a society's declining commitment to religion, i.e., the rise of secularism (Baker 2015; Gauthier and Martikainen 2016; Bauman 2005 and Baudrillard 1998). The previous group of researchers posit that the ideology of consumption has inculcated people so deeply that even religious or spiritual practices and beliefs are now simply one further commodity to consume or eschew altogether.

Additionally, scholars of secularization point towards a theory borrowed from economics, known as rational choice theory. RCT posits that "consumers" of religion make a rational choice regarding following a religion at all, or which parts to focus in on, and, in other cases mixing and matching tenets from different faiths (Mariana, 2008; Reitsma; 2004, Casanova and Inglehart 1995).

The data for this study comes from a multi-nation effort to assay the religious values of college attending youth called YARG (Young Adults and Religion in a Global Perspective). This survey was developed by researchers at Abo Akedemia in Sweden. The survey has sections that deal with a person's religiosity, what their social life consists of, whether they have volunteered to help others within the past year, and a 57-question battery that measures values of individualism, conservative and neutral moral values. The total sample size of all combined YARG data is 6,959. The survey was administered in 13 nations, in some countries more than one location was sampled attempting to capture some 
of the country's diversity. The sample also includes 1,995 Portland State University students' responses that I administered under the direction of Dr. Stepick.

Following an extensive review of the literature Chapter Two concludes with the literature gap and research questions, as well as summarizing the methodology in Chapter Three. Chapters Four and Five address the four specific research questions. Chapter Four addresses the sampled university students' secularity versus religious leanings, along with an examination of conservativism. and cosmopolitan humanitarianism. In Chapter Five I conduct a linear regression examining whether young people are still moral while being largely irreligious. This linear regression centers on two questions from the survey: how religious the respondents rank themselves, and whether they have volunteered in the past year. The final piece of research deals with the concept of "cosmopolitanhumanitarianism" which in the social sciences is taken to mean possessing an open attitude towards cultural differences, a feeling of loyalty toward humankind and notions of being a world citizen (Hannerz, 2004; Skrbis \& Woodward, 2007; and Vertovec \& Cohen, 2002). Cosmopolitan/Humanitarianism of the sample will be examined with a logistic regression measuring whether religion influences Cosmopolitan/Humanitarianism. While we have no "Cosmopolitan/Humanitarian" variable in our sample, the literature review will draw a close line between Shalom Schwartz's value of Universalism as a proxy for Cosmopolitan/Humanitarianism. Chapter Six presents the conclusions of the thesis and summarizes the findings with respect to the research questions. 


\section{Chapter Two}

\section{Literature Review}

Many of the classical sociologists such as Comte (1973), Durkheim (2001), Weber (1930), and Marx (1972) made assertions of the superiority of science and particularly of sociology over religion. Classical secularization theory, championed by some of the most pivotal of sociologists, holds that with increasing education and modernization, religion may eventually disappear altogether. While religion remains far from dead, it has certainly lost a great deal of its power and influence, at least in the West, compared to the time of the classical sociologists (Davie 2007). This literature review addresses six crucial facets of secularization outlined below, including its definition and history which inform my hypothesis: the absence of religion will cause young people to hold values that are more closely aligned with individualism.

This chapter explores literature relevant to the research purposes of this thesis. It is organized into the following sections: 1) Individual values, 2) Profile of secularity and its history and social contexts, 3) Rational choice theory and consumerism, 4) Individualism and post-materialism, 5) Secular morality, 6) Cosmopolitanism and religion, 7) Religion and volunteering, and 8) The Pacific Northwest and secularism. The chapter closes with a section on the gap in the literature at the intersection of these bodies of literature. Finally, I articulate the contributions of this study. While there is considerable literature on secularism and values (Li and Bond2010; Stewart et al., 2001; and Ciecinuch 2015). This 
research focuses on the effects of increasing secularism is having on the values of those attending college.

\section{Individual Values}

Values can be defined as the importance a person places on a thing, feeling, idea, or philosophy. As such, values are critical motivations of behaviors and attitudes. Values are also used to justify the choices people make as appropriate and worthwhile (Saroglou and Muñoz-García 2008). The values a person holds affect the degree to which that person will fit into a group of people. The sense of belonging is an absolutely crucial aspect of human behavior which is required in order for people to thrive (Anglim et al. 2017). While personality traits describe who a person is, values describe who a person envisions themselves capable of becoming, a crucial distinction that affects behavior (Inglehart 2018).

Values are motivational goals, many of which meet our basic human needs. Shalom Schwartz divides needs into three distinct categories: biological (food, water, shelter, safety), coordination of action with others, and the need of groups to survive and flourish (1992). Traditional, organized, hierarchical religion has been historically strongly associated with the formation of values (Baker 2015). However, as Western society has become increasingly secular, values arise from other institutions or areas altogether.

Although Baker defines several discrete categories of religion, he also envisions a spectrum of secularity. On one end of the spectrum, we would find a strident atheist or agnostic. In the middle we might observe those who, for example, consider themselves Christian (or Muslim, Jewish, Buddhitst etc.) but do not formally belong to any 
congregation or attend structured religious activities, such as a lapsed Catholic who does not attend church but nevertheless still believes in God and prays intermittently, in private. On the other end of the secular spectrum, we would discover an avowed atheist, openly opposed to any type of religion or spirituality. The non-secular are those who "officially" belong to a congregation of like-minded believers, and regularly attend worship services at officially sanctioned places of religious gathering (Baker 2012).

With the rise of secularism, the sociological lens has been trained on the topic of individual values. The Schwartz theory of individual values, discussed at length later in this literature review, is but one of several prominent conceptions of values. Janek Musek (1993) from the University of Ljubljana in Slovenia, proposes what he terms the "Structural Hierarchy of Values" (STHV). STHV theory envisions values changing as we reach different stages of life. Musek's theory holds that in youth and early adulthood we are guided towards hedonic and self-satisfactory values, whereas, middle aged and older adults, are directed more towards values of morals and personal fulfillment.

Milton Rokeach envisions values as a concentric system of ideals, that are most important to a person, moving outward to those that are most peripheral. Rather than people having a unique set of values, Rokeach saw all people sharing the same values, but the difference lied in how important each value is to the person (Cieciuch, Schwartz, and Davidov 2015). Gordon Allport and Philip E. Vernon (1990) put forth a theory of values that draws upon a person's evaluative interests and attitudes. As the foundation for perceptions, values are likely to influence one's behavior. The pair outlined six major value types: theoretical, economic, aesthetic, harmony, social, political, and religious. 
Lastly, the philosopher Robert S. Hartman (2011) conceptualized what he referred to as systematic values, i.e., conceptual cognitive scripts that exist in people's minds. Ideals, norms, rules, doctrines, and logic systems are all examples of Hartman's systematic values. The philosopher constructed what is known as the Hartman Value Profile that consists of two parts: eighteen paired value combinations where one part is negative, and the other is positive. Depending upon the combination, a value can be enhanced or diminished.

While there has been a great deal of research and writing done on values there are some areas of the literature that are incomplete (Roccas, Sonia \& Sagiv, Lilach 2017). There is a noticeable paucity of literature on the values of young people and religiosity, be they teenagers or college students. There is some literature on the effects of religion, both traditional and in its myriad secular forms regarding values of the youth. Although, there is also little or no research on youths whose parents are openly disparaging of, or antithetical towards religion. What would the children of these secular person's values resemble? While these, and many more areas are all worthwhile avenues for research this thesis examines the values of college-attending-young people from thirteen different nations. One sample of this larger study is from Portland State University, which is located in the area of the U.S. that is the most "non-religious", the Pacific Northwest. In a way some of the attitudes Pacific Northwesterners take toward religion mirrors the increasing secularity in Western Europe (Killen and Silk 2004). Consequently, if trends remain the same this research may be an important examination of what secularism in other major portions of the United States will embody in years to come. 


\section{Profile of Secularity}

This research focuses on secularism and values among college aged youth, and as such secularism needs to be defined within this research framework. Baker and Smith see five basic categories of religious beliefs: the "theistic", "non-theistic", "atheists", "agnostics" and the "religiously non-affiliated" (2015). The last category includes those who hold private spiritual beliefs, but do not consider themselves of one faith, or attend religious ceremonies. The theistic describes persons who would be considered “traditionally religious," i.e., attend church (Mosque, Temple etc.) on a regular basis, and are involved with their place of worship. The non-theistic category might include people who have personal belief systems that do not involve a direct relationship to a deity. An atheist, according to Baker and Smith (2015) is simply someone who holds no theistic claims whatsoever, whereas an agnostic is someone who sees theistic claims of any kind as unverifiable. Following from Smith's five basic categories of beliefs, secularism is concerned with atheists, agnostics and the religiously non-affiliated.

In contrast, mainstream traditionally religious persons are those who regularly attend worship services in an "officially sanctioned" place of worship. These people are also members of their local congregation, and they attend "church" as prescribed by their respective faiths. These folks also join in social and community functions associated with their local congregation. The secular, in contrast can be defined as those who may or may not be religious. If the secular are "religious," they are so only on a personal level, and do not formally belong to an organized religion. These people defined as secular may also be non-religious, and/or have a hodge-podge of religious ideals that they have adopted. 
Classical secularization theory has deep roots in sociology, including the likes of Marx, Freud, Weber, Durkheim and others, who held that increasing education and modernization would lead to an eventual erasure of religion altogether (Calhoun 2011). Academics agree that secularization involves the diminishment of "traditional" religiosity, and declining rates of church attendance (Baker 2015). Some scholars define secularization as a simple decline in demand for religion (Bruce 2016). Additional scholars see secularization as a decrease in respect for, and adherence to, religious authority and dogma (Gorski and Altinordu 2008).

Although many observers of religion and secularization speculate on the exact causes of departure of large swaths of societies departure from religion in the West beginning in the 1960's several theories have been proffered as contributing factors. Some scholarly work sees the rise in Western reliance on, and trust in, science and technology, as contributing to what some have termed, "scientism." This "ism" involves the abandonment of religion, and its replacement by trust in rationalism and science, in order to provide both meaning, and solutions to human problems (Morvillo 2010; De Ridder, Peels and Woudenberg 2018). The term scientific naturalism refers to the removal of god from the equation in which humankind was created. This idea stems from Darwin's (1964) work and has gained more and more credence as it has been embraced by the scientific community. For those who are secular, science is very often a crucial element in constructing a narrative identity and deriving a sense of ultimate purpose and place in the universe (Baker 2015). 
In addition, the social upheaval of the 1960's in the western world is another speculated cause of secularization. During the countercultural revolution, many questioned the legitimacy of "traditional institutions". The church was one of many of society's pillars that saw their validity being examined by the youth of the day. For those who were nominally religious, the traditional, hierarchical, sexist, and largely patriarchal institutions seemed out of touch with changing values. (Beck 2010).

To illustrate secularity, the decline in church attendance is one of the most often used indicators for measuring the decline of religiosity and concomitant rise of secularism (Smith 1998). A majority of this research is carried out via survey questions, which often ask questions such as, "How often have you attended church, or religious services of any kind in the past month ?" (Rossi and Scappini 2014). Critics such as Tom Smith contend that survey data can be misleading, and people are likely to overreport how often they attend religious ceremonies, thus inflating the numbers of supposedly traditionally religious people in the industrialized West (1998).

For example, the US General Social Survey (GSS), as reported by Rossi and Scappini (2014) indicates that self-reported rates of church attendance In the U.S. have undergone a slow but steady decline beginning in the middle 1960's. Those who claimed they went to church at least once a week fell from $22.3 \%$ in 1975 to $18.7 \%$ in 2010 (Rossi and Scappini 2014). In more recent findings, a 2018 Gallup poll reveals that only 50\% of Americans claim that they are members of a church, down from $70 \%$ in 1976. While the same poll finds that only $17 \%$ of those aged $18-29$, attend at least once a week, with $26 \%$ (the plurality of the sample) attending "never" (Gallup 2019). 
On the whole church attendance levels and survey information leave us with a profile of a secular person in the United States. Kelly Strawn (2016) examines GSS survey data from 1976 to 2016, painting a clear picture of what secularity looks like in the United States. Religious "Nones” (those who are not religious in any manner secular or otherwise) are more politically liberal than those who are affiliated with a "formal religion." Those who are not religious are more likely to be male than female. "Nones" are also predominately white. Religious "nones" are also less likely to be married. Finally, those who are more educated tend to be less religious.

Figure 2.1 (Strawn 2019)

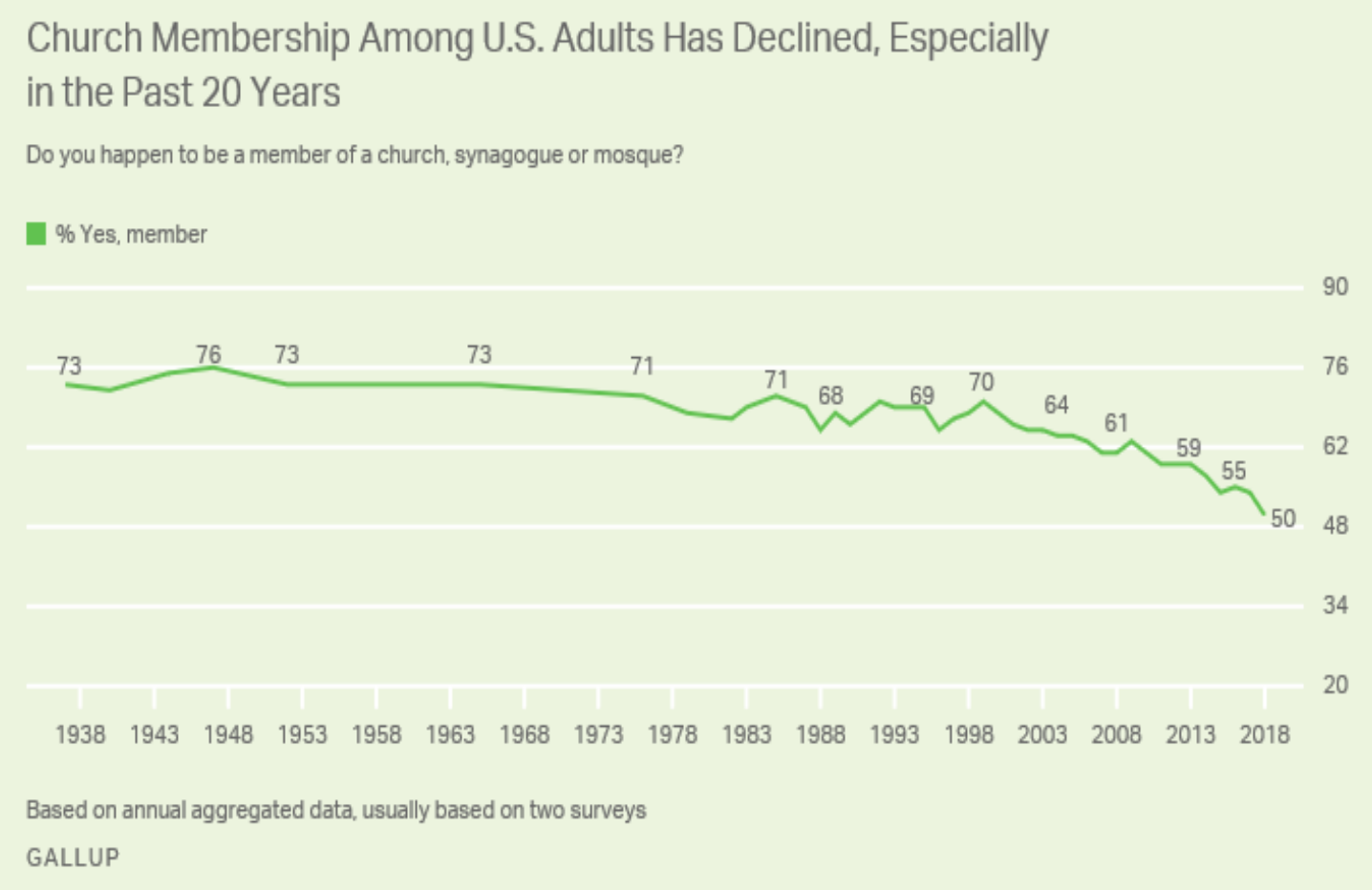

While the decline in religiosity in the U.S. is empirically unassailable, its causes are more equivocal. Some scholars point to television, and growth in mass-media in the post-war years (Wilcox 2011). The world's religions, with the exceptions of Judaism and 
Christianity, which at one point in time seemed far away and exotic to those in the US and other Western nations, were no longer experienced as such (Meyer and Moors 2006). The media theorist Marshall McLuhan posited that the rise in TV shrunk the world, making every place seem as if it were accessible, and in his words, we became "one global village" (McLuhan 2013:45). In addition to TV and the media, humankind after the Second World War seemed ultra-modern and scientifically advanced, and in many religious theorists' views, to be modern was to be secular (Casanova 2004; Wilkins-Laflamme 2016; Meyer and Moors 2006). Being modern meant leaving religion behind regarding it as a "superstition," that did not belong in the "modern" $20^{\text {th }}$ century (Dobbelaere 1999). Increasingly, people in the West began to place more and more faith in what science is able to explain away, pushing religion, and the idea of god, into a smaller and smaller box (Thomas 2010).

In addition, politics and religion remain intricately linked. While no one single tradition has ever dominated the religious landscape in the United States, religion and specifically, frequently conservative Protestant evangelical religion, has increasingly become a factor in the politics of the nation. The polarized views of a majority of the U.S. have produced a deep divide between social liberals who tend to be more secular, and social conservatives who tend to be more politically conservative and more religious (Kosmin 2006). According to the American Religious Identification Survey (ARIS) 2001 poll, respondents were almost equally divided among the three main parties, Democrat and Republican, as well as those considering themselves political Independents, i.e. not identifying with any organized party (Corbett 2014). Again, looking at ARIS data, of those who identified as "religious" 41\% were Republican, 28\% Democrat and 24\% Independent. 
Conversely, of those who identified as secular, only $19 \%$ were Republican, with $32 \%$ Democrat and 43\% Independent (Kosmin 2006). The religious traditions that support the Republican party in overwhelming numbers are Mormons, and various denominations of Protestant Christianity. On the other hand the faiths that tend to support the Democratic party are people of Judaic faith, "other religions" (unspecified), Baptists and Catholics (Corbett 2014). In a recent look at differences among generations Pew found that the Silent Generation (born 1928-1945) were 84\% Christian. In the Baby Boom Generation (born 1946-1964) only 76\% identified as Christian. Additionally, Generation X (born 19651980) has only $67 \%$ claiming Christianity as their faith while in the Millennial Generation (born 1981-1996) under half (49\%) claimed Christianity as their religion of choice (Pew 2019). Clearly religion and secularity can be correlated with some aspects of politics, but because of the plurality and openness of religious expression in America, no one faith dominates politics.

\section{Family Religiosity}

Family religiosity relates to young people in several ways. Most of the literature on family religiosity focuses on several main areas. Most of the literature focuses on family religiosity is related to drug use, sexual behavior and activities, mental health and delinquency and how they influence later religiosity of young people. (Jerf, W.K et al. 2009; Ganga and Kutty 2013; Ray, Merril et al. 2001; and Hagland, Kristen \& Fehring, Richard. 2009). The literature suggests that a high religiosity of the parent's generations results in the behaviors in about in around $60 \%$ of the US population, and that said behaviors result in lower religiosity for the current generation (Moscati, Arden \& Mezuk, 
Briana. 2014). Several studies demonstrate via survey data that the higher an individual's family religiosity, the likelier one is to possess a "volunteering posture" (Essen, Johan et al. 2014; Johnson et al. 2013; and Paxton, Pamela et al 2014).

\section{Rational Choice Theory and Consumerism}

Consumerism and Rational Choice Theory are concepts that lend themselves to understanding secularism in an age where nearly everything-including religion-has been commodified and competes in a marketplace for "buyers." Following WWII, consumerism reached new heights in Western societies, The U.S. included. Baker (2015b) argues that consumerism became the organizing principle of society. As Gauthier and Martikainen (2016) note, the consumer became an identity; consumerism became a way of life that permeated all facets of the day-to-day existence of people. (2016). Zygmunt Bauman identifies the "consumerist syndrome "as a phenomenon in which everything is, or should be, handled as if it were a commodity, and consumer life is one of infinite experimentation, novelty, and sensational gathering supplied by the market. The market refers to everything, religion included. Consequently, the ideology of markets has usurped differing ways of conceptualizing areas of society, integrating religion into the realm of the commodity (Baudrillard 1998).

Thusly, people have begun adopting identities as consumers. Each person is a project in and unto themselves. This "project" is created by the individual choices people make regarding what they consume. As sociologist Coilin Campbell relates, "we are what we buy" (Staff 2002:348). Consumption is now a part of everything: the college one attends, the places one chooses to eat, the clothes one wears, and interestingly the religious 
choices one opts for (Casanova 2009; Davie 2007; Iannaconne, Zafirovski 2013). In this environment nontraditional religions spring up in an atmosphere fertile for the ideology that consumerism demands (Baudrillard 1998). These new religious or secular belief systems stress orthopraxy, correct conduct, as opposed to faith or grace, the belief in something supernatural)over orthodoxy. (Gauthier and Lehtinen 2013). In this rush to define one's self by the goods and services a person consumes, religion is either ignored altogether, or some form of secularism is found in its stead. The values of consumerism and individuality pervade our entire society, and the youth of today have been steeped in this principle from the moment they enter the world. Thus, their values should mirror that of a consumer: self-interested, individualized, and concerned about building an outward looking appearance of a self which is based on choices of consumption or nonconsumption, religion included.

Consistent with the above perspective, RCT (rational choice theory), a tenet borrowed from behavioral economics, argues that there is a market place of religious ideas competing for people's attention (Mariano 2008). The idea that religious tenets have become commodified fits within the scope of neoliberal thinking that dominates our age (Reitsma 2004). Religious philosophies have entered a market of ideas seeking adherents, and people either consciously or unconsciously pick up on certain ideas as individualistic consumers, and make religious tenets their own, on their own privatized, individualistic terms. In an important sense, from the perspective of RCT, religion has become less social and more individualized, as envisioned by neo liberalism. Commodification of "everything" is a central tenet of neoliberalism, which has come to dominate the West and other parts of the world for the better part of four decades (Reitsma 2004). 
Jose Casanova and Laurence Iannaccone are two of the most widely respected proponents of rational choice theory. These two scholars have published, lectured and conducted research on RCT, secularization and religion (Alexandra Gheondea-Eladi 2013). The two scholars' work is very nearly identical and will serve as the main theoretical underpinning of this thesis.

Casanova's influential overview of secularization identifies three separate processes: differentiation, decline, and most importantly for this study, privatization (2009). Differentiation refers to the experience secular Westerners feel apart from the religious realm. For Westerners he argues, there is extraordinarily little reality beyond that of the rationality of science. Casanova refers to "decline" in his work as the diminishing power of organized religion to hold the imaginations of a "modernizing West." One of Casanova's main theses is that modern humans have grown past the superstitious need for religion. For Casanova, to be modern means to be secular (2004). "Privatization" refers to the theory that religious ideas have entered the realm of the private individual, and function on more of a personal basis, as opposed to the collectivity seen in religion prior to the 1960’s (2004). For Casanova (2009) and Iannaccone (1995), picking and choosing bits and pieces of one religion, or combining portions of others, to create an individualized, selfproduced creed, makes sense in western societies, who consume in an individualistic fashion, no matter what the commodity (Knoblauch 2011).

Casanova speaks of secularism in terms of "the naturalization" of non-belief. In this form of proposed secularism, the idea of being nonreligious is seen as the default position, or the normal setting of being human in modern times. In addition Casanova 
posits that the more modern the society, the more secular it should be (Casanova 2009). While secularization is on the rise in the U.S., it has not reached the high levels seen in Europe, and the U.S. has remained fairly religious in comparison to the rest of the industrialized West (Gorski and Altinordu 2008). There are exceptions however: the Pacific Northwest is one of the most "unchurched" areas of the nation. A 2007 Pew research poll finds that only $63 \%$ of those polled claimed to be religious at all (Frykholm 2008).

Equally important, is the work of Laurence Iannacone regarding rational choice theory and religion. Similar to Casanova, Iannacone envisions "consumers" opting for a religion in an open market place of faiths (Iannaccone 1995). For Iannacone religion is not simply about the supernatural: it is about group membership, receiving and giving help and social cohesion. He envisions three markets for religion: 1) perhaps most importantly for this study, at the household or individual level, 2) the congregational or church level, and 3) entire markets or nations and even larger areas. Iannacone argues that religions must be responsive to the demands of people, and that those faiths that ignore people's needs will not be successful (Robertson and Woodhead 2012).

Finally, Casanova and Iannacone's theories of privatization squares with the concepts of rational choice theory, in that both religion and a person's "consumption" of religion have been privatized, in keeping with the neoliberal-ideology of our age only applied this time to notions of religion (Casanova 2009).

A number of scholars in contrast claim that RCT cannot explain secularism, because religion is inherently irrational and cannot, or at least should not, be relegated to 
the logic of the "marketplace of ideas." As Iannacone relates in an interview for the Religious Studies Project, many cult members are often found to be quite rational and have made a somewhat conscious decision to join the cult. He further relates that at one point the very established religions of the world must have seemed cult-like, and undoubtedly early members made a choice to join (Gauthier and Lehtinen 2013). Casanova replies to critics of RCT by citing the similarities between religions and Narcotics Anonymous or Alcoholics Anonymous. Both contain a spiritual quasi-religious element to them, and short of court-ordered attendance, many of the groups' devotees made a conscious choice to attend these meetings. In other words, Casanova envisions that these groups serve remarkably similar social functions to mainstream religion, and people have consciously opted to join both (Casanova 2009).

Lastly scholars have noted that since the ideology of consumerism has become so internalized among the Western nations in the last four decades, social forces that kept people attending church, and remaining part of a religious community, began to lose the power that they had prior to the counter-cultural revolution of the 1960's with its emphasis on individualism and free choice (Jerolmack and Porpora 2004; Gorski and Altinordu 2008). People now face fewer negative social consequences for not going to church every Sunday. It matters less what a person's parents, friends or extended family think about their religious convictions or lack thereof. Individuals began to explore for themselves what religion or spirituality mean to them, and just exactly how they would express it (Davie 2007). 


\section{Individualism and Post Materialism}

While RCT, consumerism, mass media and globalization may help explain some of the drift away from traditional religion, they do not predict which way the drift should go, other than it is likely to be more individualized, less social, and perhaps encompass non-Western beliefs. But what form will the content of these beliefs assume? For this, Robert Inglehart's pioneering work on post materialism, the shift towards post material needs, those higher on Maslow's hierarchy of needs pyramid is helpful (Inglehart 1981a). Since the end of WWII, according to Inglehart many if not most people in advanced capitalist nations have tended to have their basic human needs met, such as food, water, shelter, and safety (Of course it is crucial to note that not all people in Western nations have their basic needs met). This leaves the higher order needs, such as self-actualization, open for fulfillment, and exploration (Sage Reference 2019). Inglehart theorizes a shift from material needs of economic and objective demands, to those of self-expression, quality of life, and autonomy (Maslow 1942; Inglehart 1977). Inglehart describes two processes that occur in tandem to bring about the shift toward individual values: 1) The legitimacy that people once held for hierarchical institutions begins to decline, and 2) a decline of confidence in institutions that have hitherto been taken for granted as pillars of society declines (Inglehart 1977).

In addition, Inglehart sees the rise of increasing media (TV, Radio, Movies etc.) alongside knowledge industries as aiding in propelling trends of individualism. Knowledge industries require increasing education, which Inglehart also sees as contributing to individualization, furthering one's education leads to better cognitive skills, tends to make 
people more liberal, less dogmatic, and less ethnocentric (Inglehart 2018). Increasing levels of mass media consumption can also be seen as an agent of change, in that they communicate dissatisfaction, alternative lifestyles and "dissonant signals" (Inglehart 1981b). If we take into consideration the mass-media inundated environment we live in today, alongside the rise of social media, people's values are likely speeding toward individualization at a quicker pace. All Inglehart's forces of change, which our current media environment is delivering to our youth at even faster speeds, should increase the move towards individual values.

In addition to Inglehart's other notions regarding the move toward individualism, he theorizes a laundry list of effects that post-materialism has in pushing values in the direction of individualism. Post-materialistic (PM) people are less parochial and more cosmopolitan. PM individuals are more open to innovation and responsive to new ideas, such as new religions. PM people are increasingly dissatisfied with hierarchically and bureaucratic forms of organizations, such as religion. PMs also tend to be more prosperous, which lends itself to values of individualism (Inglehart 2018).

Many have assuaged that Inglehart's Post-material world has not been fully realized for large portion of those residing in the West. For example, the U.S. has a large homeless population and an even higher number of people who live on the brink of homelessness. While for some Inglehart's theory of a post-material world is a reality it is worth noting that this is by no means a default reality for many in the west. Inglehart argues that through "intergenerational replacement" successive generations will assume the post material values of their parents, and become more and more post material 
(Inglehart 2018). Generations who have always had their material needs met will be likelier to place greater emphasis on individual attainment, personal freedom, and a healthy democratic society (Banchoff 2007). The French sociologist Jean Baudrillard sees values shifting towards an environment where, "need[s] of the individual to differentiate himself as one more element in the repertoire of individual needs" (1998 Pg. 92.) Yet, Inglehart remains somewhat vague and not particularly empirical about the form of post-material values. But what are the values of a post-material, secular world?

\section{Secular Morality}

The values of young people may stem from origins other than traditional religious outlets. The notion of secular morality is not new and is often found amongst various societies throughout the globe. Simply speaking, secular morality is the notion that religion is not the only place to find a moral code of ethics or action (Brandt and Rozin 1997). There are three basic frameworks of Secular Morality (SM). The first framework is consequentialism (Norman 2017), this line of thought posits that there exist normative ethical theories that provide a map for whether an action is right or wrong; in essence a morally right act will produce a morally right consequence (Vroman 2013). The second framework of SM is known as free thought, which is more of a philosophical stance that envisions that people are imbued with free thought, and therefore have the capacity and responsibility to think for themselves, and reason logically as to what constitutes moral actions free of religion (Calhoun 2011). The third and final framework is known as secular humanism, this stance on morality holds that people are fully capable of being moral and ethical without the aid of religion. Furthermore, a core tenet of this way of thought is that 
religious ideology must be carefully examined by each person, and not inherently accepted based on faith alone (McKay and Whitehouse 2015).

While moral secularism has its detractors, mainly from various religions, there are some empirical findings that support the idea that religion is not necessary for morality. In Philip Zuckerman's book Society Without God (2010) the author notes that the Scandinavian nations are amongst the most irreligious, yet they are the best educated, least violent, and most likely to care for the poor and vulnerable. In the same work Zuckerman theorizes that religion has positive effects on morality, but that secular humanism does as well. In another example, a 2012 article used U.S. General Social Survey data to demonstrate that non-religious persons had higher scores on tests that indicated that they were inclined to reflect generosity and engage in random acts of kindness (Saslow et al. 2013). In contrasting however, Pew and Gallup Global polling, results from 2005 and 2006 indicate that those who have attended a religious ceremony in the past week were more likely to donate money, as well as time to help people in need, or engage in moral acts (Smith and Stark 2009).

\section{Cosmopolitanism and Religion}

Cosmopolitanism is often thought of as a wealthy person's trait, jet-setting around the globe, and thus obtaining a wider and more accepting world view. In social science the term is thought of differently, and mostly regards an openness to cultural variations and diversity on a conscious level, a certain allegiance with humanity, and a notion of being a “world citizen” (Hannerz, 2004; Skrbis \& Woodward, 2007; and Cohen, 2002). Scholars envision an everyday, "ordinary" cosmopolitanism, in which those who display these 
values are "rooted" in their communities, loyal to them, but still display an openness towards the world outside, along with a shared sense of identity with all peoples (Pichler, 2009; Wang; 2018 \& Appiah 2017).

Additionally, scholars have identified cosmopolitanism with liberalism and secularism. Unfortunately, religion is not usually studied in conjunction with this Cosmopolitanism (Appiah 2017). When religiosity is brought into consideration it usually has the effect of pitting religious identity against an outward and cosmopolitan view of outgroup persons, however religion can also tend to emphasize differences and alienate outsiders (Modood, 2019; Koopmans 2015).

\section{Religion and Volunteerism}

Volunteering is an activity that benefits secular and religious organizations as well as private individuals. There is a fair amount of literature connecting volunteering to religion (Ammerman 2005; Unruh and Sider 2005; Wilson 2000). Musick and Wilson (2008) see religion as a "feeder system" that impels young people to volunteer at their place of worship, and thus motivating them to undertake good deeds in the secular world. With increasing secularism, religion and religious affiliation has become an area of note. As such, does the individual value of volunteering still exist if religiosity slowly fades away (Yeung 2004)?

Consequently, individual religiosity is also seen as a mechanism that increases volunteering, prayer is viewed as intercessional and is based on care for others. (Ladd \& Spilka 2002). In summing up this brief look at the literature regarding volunteering and religion, it is clear social networks play a much larger role in determining volunteering than 
religious beliefs (Becker \& Dhingra 2002). Lim and MacGregor (2012) observe that at a micro-level, if a person has close friends who are involved in a religious group, the chances of them volunteering is increased by contact with these close friends and peer-groups.

Finally, since the empirical data in this thesis empirically uses a multitude of samples from different nations, it is worth looking at macro-level contextual data regarding volunteering and religion. In research including a data set of 33 mostly Christian nations, Curtis et al (2002) conclude that nations with larger variety in Christian denominations see more volunteering than those where Catholicism is the majority form of Christianity. Ruiter and Degraaf (2006) hypothesize a positive correlation between the degree of national devoutness (a strong belief in religion, worship, service, and piety), and levels of volunteer work. They base their reasoning on the generalization of the network effect: in devout countries the chance that people (whether they are themselves religious or not) have religiously active persons in their own social networks is great, and consequently, their probability of being aware of tangible volunteer opportunities, or being asked to participate in such activities is higher than it would be if they lived in less devout societies. As an indicator of religiosity, the authors use the average church attendance computed from each national sample. Parboteeah et al. (2004), build a country-level marker of religiosity from a national religious service attendance dataset. The pair find that religious attendance and volunteering are positively correlated. Because secularization seems to be a continuing process in post-industrial societies, Ruiter and De Graaf (2006) conclude that volunteering should decrease due to lack of close peer-group influence from religious friends within their respective social network. This current research hypothesizes that scholars such as 
Ruiter and de Graaf are wrong-that young people will still volunteer, perhaps spurred on by secular peer-groups.

Finally, volunteering is important to this study for a few reasons. Firstly, volunteering to help another person, place, or thing demonstrates that a person has a moral nature. Second, volunteering is an expedient way to measure whether someone has moral equivalency of peers raised religiously. Lastly, measuring values in an increasingly secular world is what the crux of the YARG survey instrument aims to accomplish. As such, volunteering is a clear variable that demonstrates morality, and can be easily measured (Johnston, Joseph 2013). In other words, measuring values of morality such as compassion, forgiveness and kindness can be somewhat ambiguous, whereas volunteering is a tangible act that can easily be measured. As such volunteering is a simple tool for measuring morality, and often it is the simple tools that function the best.

\section{Secularity in the Pacific Northwest}

The value profile of college aged students in the Pacific Northwest is of interest as the region is one of the least historically "churched" areas of the nation (Block 2016). There has been growing research charting the possible origins for the area's lack of religiosity. The Pacific Northwest (PNW), which consists of Oregon, Washington, Alaska, and British Columbia, has historically been viewed as the last frontier "settled" as the United States expanded. Early settlers were mostly men, often transient, who much like now tend to be less religious than their female counterparts (Killen and Silk 2004). As Tina Block (2016) points out in her book The Secular Northwest, The North American West attracted and attracted an inherently more eccentric and idiosyncratic kind of people. 
Further, religion had a difficult time finding roots in this relatively sparsely settled and geographically expansive region. No one religion has ever been able to garner numbers large enough to be considered a dominant public force in the PNW (Killen and Silk 2004). Institutional power was difficult to establish for any one religion in the PNW because of the successive and frequent waves of immigration into and out of the region. There was too much cultural diffusion for any one established church to gain a foothold long enough for it to lay down roots socially in the region (Hammond 1992).

In addition, geography is a key identifying theme for those who inhabit the PNW. The region itself, according to Block (2016), can be viewed as a sublime presence which often takes the place of a divinity, constituting a sort of naturalistic deism that includes a respect for and awe of the geography itself. Place often gives meaning to the identities of a region's population. In the case of the PNW rugged individualism became a regional identity that pervaded many aspects of everyday life for the area's people (Frykholm 2008). This helped shape the region's religious behavior, which is largely secular and resistant to organized, hierarchical religions (Brown 2012). The scholar Killen and Silk (2004) argue that there exists in the PNW a fluid boundary between individual and social identity. Religious institutions have historically been relatively weak, and unlike other parts of the nation, there exists little or no social pressure to conform to norms of regular religious participation.

As such a portrait of the region's religiosity is mainly that of secularism, but other groups also make up the population. As of the publishing of Frykholm's (2008) work, most of the region's people consist of "spiritual but secular," who are somewhat religious but do 
not belong to a church or attend religious services regularly if at all. The "spiritual but secular" can be further split into two sub-groups. The first group are those who identify with a religious faith but do not belong to a specific congregation. The second group are the "Nones" (Strawn 2016). This group would-be people who would answer "none" to the question "what is your religious tradition, if any?" Few of the "nones" refer to themselves as agnostic or atheist. The larger of the two groups is the spiritual but secular. There also exist three varieties of religiosity in the region that might be considered well outside of traditional; these groups include the "new age/seeking movement", anti-government extremists, and nature based religions (Killen and Silk 2004). The PNW is clearly an area where dominant prevailing notions of religion are different from those in the rest of the United States.

In addition, class, race, and gender have historically played extraordinarily little role in secularity in the PNW (Frykholm 2008). Latinx, African American, and Asian persons are just as likely to be secular as white persons. Women, while traditionally more religious than men, were historically, also more likely to be secular in the PNW (Block 2016). In addition working-class people (traditionally more religious) were also historically just as likely to be secular in the PNW as those of the middle or upper classes (Frykholm 2008). The words of Tina Block sum up the region's relationship with religion best: "Belief without belonging is becoming ever more common and has long been a widely accepted way of approaching religion in the Pacific Northwest" (2016:171). If religion exists for people in the region it might be best described as religion created by, and for, the individual. 
Finally, a brief profile of the region's current religious populations clearly illustrates the area's secularity. Using data from ARIS (American Religious Identification Survey) conducted by Trinity college most recently in 2001, $62.8 \%$ of the region's population was religiously unaffiliated. This compares with $40.6 \%$ unaffiliated persons in the remainder of the nation. The PNW's largest religious denomination is Catholic with $11.3 \%$ of residents compared to $22 \%$ nationwide, almost twice as much (Killen and Silk 2004). The 2014 Religious Landscapes Study conducted by the Pew polling firm reveals that $37 \%$ of Oregon's population attends church "seldom or never." The study also found that $63 \%$ "seldom or never participate in prayer, scripture reading or religious education," meanwhile $39 \%$ of the state claim that they "meditate at least once a week" ( Washington, and Inquiries 2016). The most Recent Gallup poll finds that only a paltry $28 \%$ of people in the PNW consider themselves "very religious." The same Gallup investigation found that the U.S. southwest and southeast are conversely the most religious areas of the nation (Gallup 2020; Pew 2015). The PNW is disproportionately, predominately non-religious area of the nation, which makes it not surprising at all that most of our YARG sample also did not consider themselves religious.

With the contributions of rational choice theory, Casanova's conceptualization of secularism and Inglehart and Schwartz's ideas around individual values and postmaterialism, a theory regarding our sample of undergraduates at PSU can begin to emerge. Using this theoretical framework, and Pew (2015) And Gallup's (2020) polling data it seems likely that those who are either non-religiously affiliated, atheistic, or agnostic will have higher scores on the values most strongly associated with individualism. Similarly, at 
the group level, I expect that PSU students will be less likely to affiliate with religious institutions and more likely to express individualistic values.

Finally, I propose to use Schwartz Values of Universalism and Benevolence as a stand-in for cosmopolitanism, as the definition of both values within the social sciences is nearly identical. In a paper from 2012, Schwartz et al. further refines his original basic ten values by introducing nuanced versions of the initial values. In this case Universalism is divided into three sections: "Universalism-Concern," a commitment to equality, justice. and protection of all people, "Universalism-Tolerance," an acceptance and understanding of those who are different from oneself, and finally; "Universalism-Nature," the preservation of the natural environment (Schwartz et al 2012). By substituting universalism for cosmopolitanism, we can see how the cosmopolitanism is influenced by a largely secular sample such as YARG.

\section{The Literature Gap}

There are several gaps in the literature that this research attempts to address. First, an analysis of the religiosity and values of college aged people from diverse backgrounds is lacking in the literature. While Pew and Gallup in the United States measure religious ceremony attendance (at organized collective gatherings in "officially" sanctioned religious cites) and attitudes toward religion, both organizations leave out specifically examining college students as a subset of the population (Pew 2019; Frank 2016). Moreover, most polling firms only measure attendance or attitude towards religion. This thesis aims to connect religion with personal values and determine what the values of largely secular youth are. 
Additionally, research on religiosity has trended heavily recently towards a focus on race and religion. For instance, a great many scholars have researched what effects Latinx, Muslim or other "out-group" identities have on young people's religiosity (Driezen \& Verschraegen 2020; Cornelio 2016; Vassenden and Andresson 2011; Driezen and Verschraegen 2020). The YARG data used in this research eschews race and attempts to measure religiosity against personal values using Schwartz's often cited battery of basic individual values which is described in the methods chapter. At the most fundamental level this work tries to identify what values young people have in a largely secular setting.

\section{Contributions of the Study}

This master's thesis aims to make several contributions to the sociological literature on secularism and human values. One of the main contributions is that this work will provide a clearer picture of what young people's values are in an increasingly secular world. The results of the combined data will give the scholarly community a clearer picture of what is important to young people and what values they hold. This thesis will add to the literature on the levels of Schwartz values college-aged youth hold in the thirteen nations who took part in the YARG study. This information will enable scholars to have a clearer picture of the values profile of the youth in this thirteen-nation study. Scholars can then possibly infer from these results what the values of other young people are.

Additionally, this research will demonstrate that, while a high proportion of the youth in this sample are not deeply religious, they still retain the moral capacity to do good in the world. To make a clear assertion that the college-aged youth in thirteen nations have the capacity to act morally, while at the same time being largely secular. There exists a 
variable in the dataset which demonstrate young people's moral convictions: whether they have volunteered or done something "good" for someone else within the prior year. This data indicates that being irreligious is not a clear indicator that young people's values are strictly selfish and self-centered.

Conversely, even though these youth seem to retain the values of altruism and service towards others, there is ample evidence that young people harbor values of individualism and collective or neutral values. While a shift towards individualism is not new, this research will demonstrate that young people hold both values at a high level. This duality of values will be discussed later in the thesis.

This thesis will address several questions not found in the current literature on secularism and young people.

- Research question 1a: How secular versus religious are college youth, both at Portland State University and at the other universities in the 13 sampled countries?

- Research Question 1b: Will the sample's college youths' values, tend towards individualism, as opposed to more conservative values and cosmopolitan-humanitarian values?

- Research Question 1: How secular versus religious are college youth, both at Portland State University and at the other universities in the 13 sampled countries?

- Research Question 2: Will the sample's college youths' values, tend toward individualism, as opposed to more conservative values and cosmopolitanhumanitarian values? 
- Research Question 3: How does a students' religiosity relate to the degree to which they are cosmopolitan/universalist?

- Research Question 3a: Does students' religiosity still relate to cosmopolitanism/universalism, after controlling for related factors?

- Research Question 3b: Is the relationship between students' religiosity and cosmopolitanism/universalism partially mediated (i.e., explained) by differences in stimulation?

- Research Question 4 How does a students' religiosity relate to whether they volunteered in the last year?

- Research Question 4a: Does students' religiosity still relate to volunteering, after controlling for related factors?

- Research Question 4b: Is the relationship between students' religiosity and volunteering partially mediated (i.e., explained) by differences in family religiosity? 


\section{Chapter Three:}

\section{Methods}

The data for this thesis are drawn from the Young Adults and Religion in a Global Perspective (YARG) project that was based in the Department of the Study of Religions of Åbo Akademie in Turku, Finland. The project administered an extensive survey instrument that focused on the values and religious subjectivities of samples of university students in 13 countries (Canada, China, India, Israel (two separate Hebrew language and Arab language samples), Japan, Ghana, Peru, Poland, Russia, Finland and Sweden, USA, and Turkey.

As described at the end of the previous chapter, this thesis addresses four main questions not answered in current literature on secularism and young people. These questions will be addressed using data from the YARG sample.

The YARG, which is included in the appendix, consists of seven main sections. It begins with a somewhat limited demographic segment. The usual demographic questions such as gender, age and income are present along with a few other standard personal variables. The survey asks where the respondent grew up, city, suburb, small town, or rural area? YARG also includes a question about discrimination, regarding what type of prejudice a person may feel that they have been exposed to exposed to.

YARG also contains a section on a respondent's social life. This section attempts to determine what a person's social life consists of? Such as whether they have close 
friends? Critically, for this research, this section includes the question, "In the past year have you volunteered to help someone other than your family and close relatives, done something good for other people, or done some charity work?" Some other crucial questions in this section regard religion specifically. YARG asks how religious a person considers themselves to be, how religious the family they grew up in was, and how often they attend religious ceremonies.

Additionally, the YARG survey contains a section concerning news and information. The respondents are asked how often they use certain media, (Radio, TV, Internet), and for what main purposes? Two questions regarding how often people use the internet, and specifically how often they engage in social media, are included. Incidentally these two questions would have made a great mediating variable for the cosmopolitanism regression, as the two are linked (McEwan, B \& Denton M. 2011; M Denton, 2016).

Next, YARG has a short section on what may be termed controversial topics. The respondents are asked a series of questions about how much they agree with abortion and, euthanasia, and what rights they believe a woman has over her own body. A contains a section on health and wellbeing follows, which delves into topics such as physical and mental health.

Additionally, YARG contains a short section on "personal details". Items like what country a person was born in. The citizenship they hold? age, and gender? As well as a section on student financial aid.

The main measure of values in this research are based on Shalom Schwartz's theory of basic human values. Because his method of measuring values is so central to this study, 
I will explain it at some length. Schwartz's approach to measuring values is perhaps the most widely used in the social sciences. In the past five years alone, his work has been cited over 50,000 times, according to Google Scholar. He has written or collaborated on nine books and over 220 journal articles (Masamichi 2009). One of Schwartz's main goals was to identify values that held constant for varying cultures, in other words what values cut across cultures (Schwartz 1992).

Schwartz theorized that values form a motivational continuum, as seen in Figure 3.1. Schwartz aimed to create a set of fundamental human values that are relevant in all societies, that serve as supervisory principles, either individually or for groups (Schwartz, 1992). Furthermore, Schwartz's set of ten original values are thought to function crossculturally because they involve three of the most fundamental needs of people on a biological level, a social interactive level. and the survival and welfare of the group a person belongs to (Schwartz, 1994).

The basic idea is that the values merge into, and out of one another. Each value supports or gives rise to other values. There is no such thing as a discrete value. We all have varying levels of all values, and they influence others, and so on (Schwartz 1996). Values tend to fluctuate over time depending on the circumstances of the society in which they are observed.

The values are based on three basic categories that are theorized to be rudimentary for human existence: biological needs, coordination of social interaction, and the survival of groups. (Schwartz 1992). As reflected in Figure 3.1, the original Schwartz value battery consists of 10 values (self-direction, stimulation, hedonism, achievement, power, security 
conformity, tradition, benevolence, and universalism) which are envisaged as continuous values, and are thought to be inchoate, not merely discrete. Schwartz originally theorized 10 basic categories of human values; self-direction, stimulation, hedonism, achievement, power, security, conformity, tradition, benevolence and universalism (Schwartz 1992). The 10 fundamental values were conceptualized as being in a circular continuum, based on the motivations of each value.

As reflected in Figure 3.2, in order to provide more explanatory value and better empirical fit, these original 10 values were later expanded into 19 categories (See Appendix for full listing) (Schwartz et al. 2012). The new model sought to build on the notion of a motivational continuum represented as a circle of values. More values were added to separate out distinctly those, that possessed "greater universal, heuristic, and predictive power" (Schwartz et al. 2012:664). The original value of self-direction, for example, was later subdivided into self-direction of thought, and of action. Universalism is subdivided into three components that make up the larger value: Universalism is formulated under concern, (commitment to justice, equality, and protection for all people), nature, (preservation of the natural environment); and finally, tolerance (acceptance and understanding of those different from oneself) (Schwartz et al, (2012). While several of the values are expanded in a similar fashion, universalism is of most importance as it is remarkably similar to cosmopolitanism, as several scholars theorize it (Hannerz, 2004; Skribis \& Woodward, 2007; Vertovec \& Cohen 2002).

Schwartz and colleagues theorized that this finer sub-divided set of values produced a "greater universal heuristic and predictive power" than the original ten (1992:664). The 
model was refined by adding nine categories based on how the values focused on attaining personal or social outcomes. The refined model adds categories that define values that promote growth and self-expansion or anxiety, avoidance and self-protection Theses expanded values express openness to change or conservation of the status quo and they promote self-interest or transcendence of self-interest in the service of others (Schwartz et al. 2012).

To measure these hypothesized 19 fundamental values, Schwartz et al (2012) have designed a survey instrument of 57 questions, in which triads of questions seek to measure each fundamental value. Schwartz theorized that values form a motivational continuum, as seen in Figure 3.1. Each of the 57 questions reflect part of Schwartz's continuum. The battery of questions asks the respondent to assess, "How much this person is like you? "on a scale of 1-6." A "1" on this Likert-type scale denotes "not at all like me," while a 6 indicates "very much like me." The mean of each of the questions that correspond to the value is divided by the number of questions. For instance, the topic of stimulation has three corresponding questions. For a complete list of construction of the ten basic values see Appendix 1. Missing values in this section are quite high ranging from 21-23\%, therefore the missing values were not replaced with the mean for the variable in question, as the threshold for that procedure is $15 \%$ (IBM 2020). Some of the values are more collective, such as conformity, while others are more individualistic, like hedonism (Schwartz 1992). It is precisely the individualistic values that are the focus of this study, as they may or may not be closer to the value profiles, of our largely secular sample of YARG from spring 2018. These 57 questions form part of the YARG survey. 


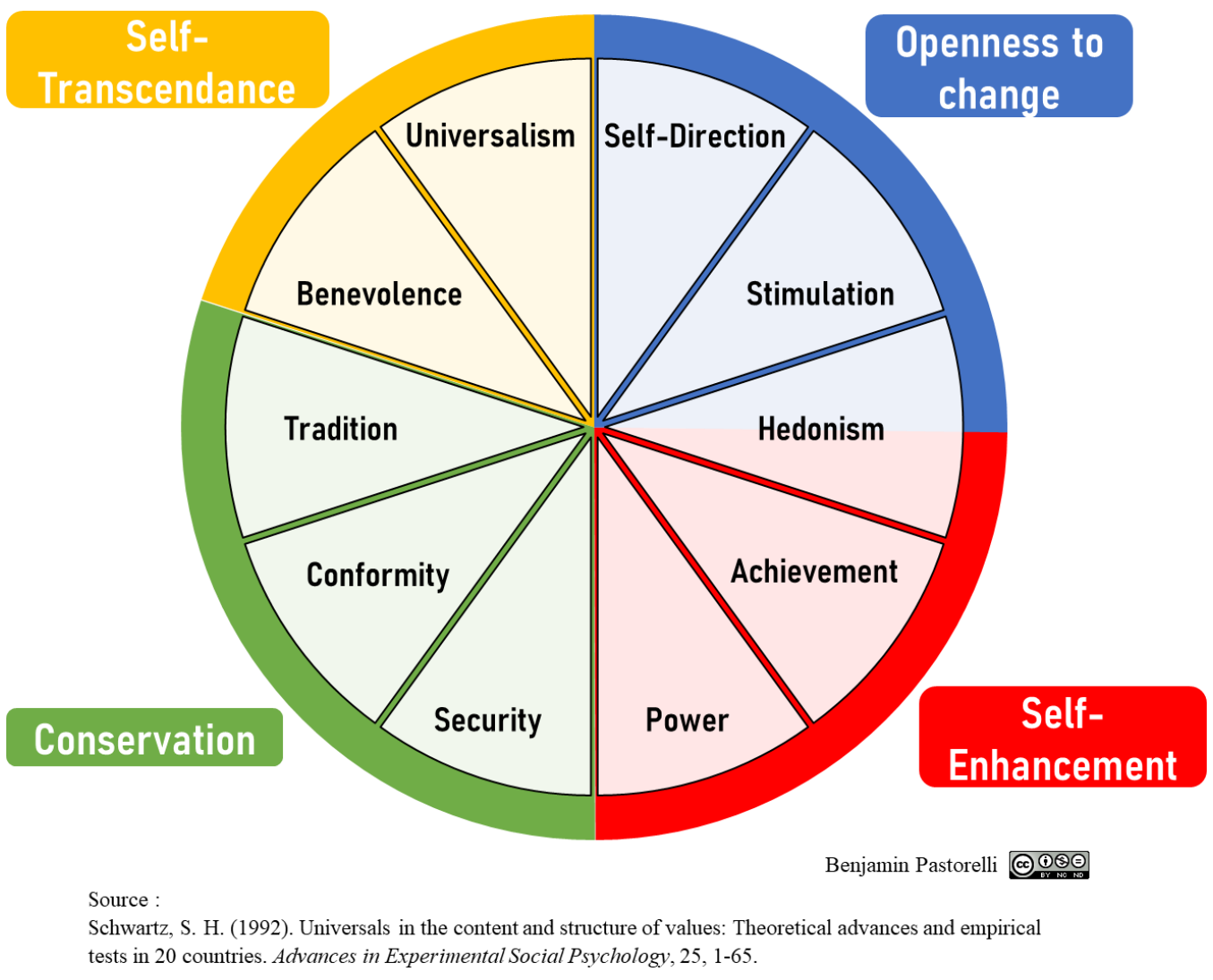

Figure 3.1 Schwartz Original Individual Values (1992 


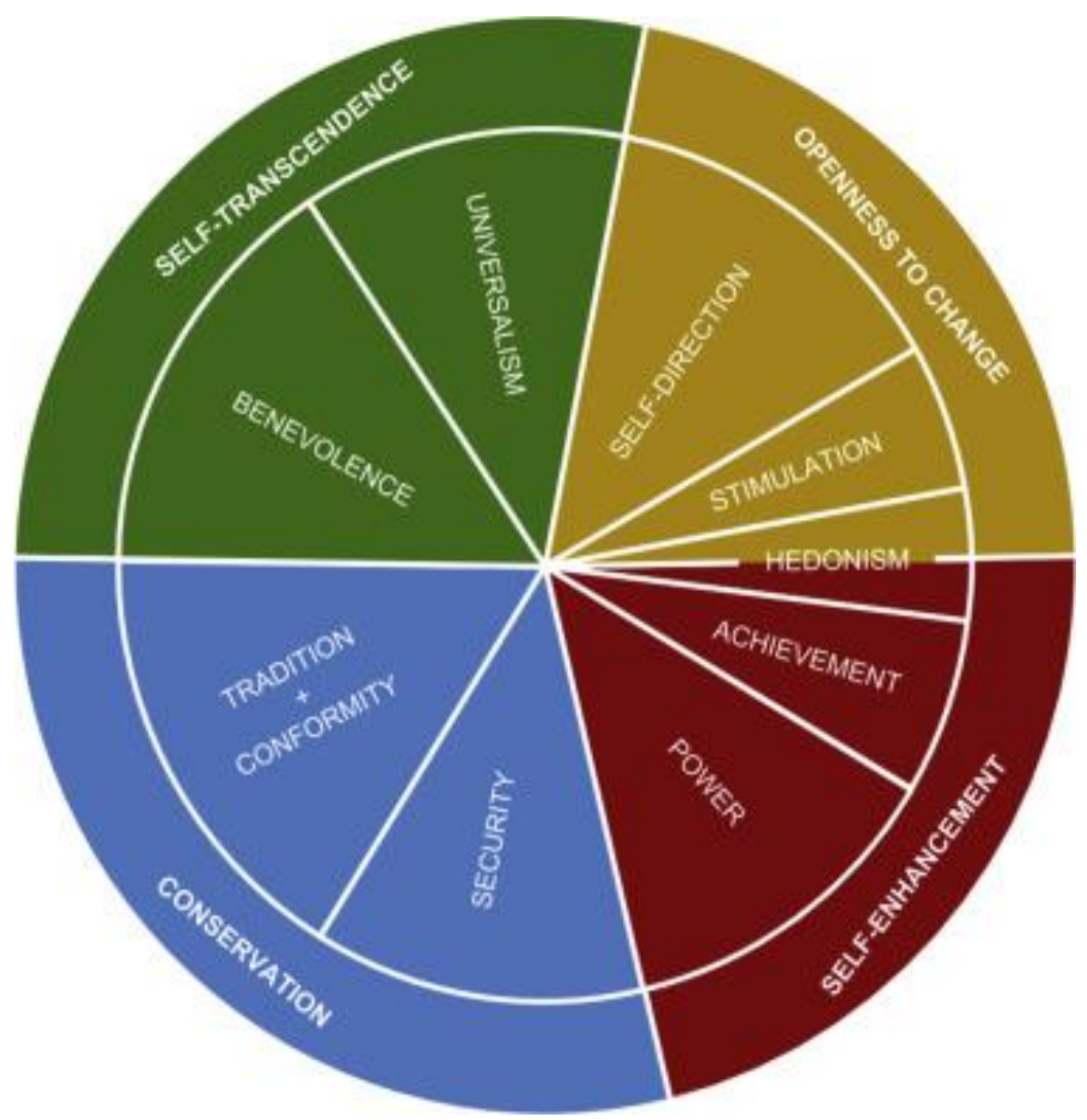

Source: Schwartz, et al. 2012." Refining the theory of Basic Individual Values." Journal of Personality and Social Psychology. Volume 10. Number 3.

Figure 3.2 Schwartz Values (Expanded Version) 


\section{Portland State YARG Sample}

The particular focus of this research is based on a sample drawn from Portland State University students in the Spring of 2018 as well as from all the other thirteen nations sampled. For the Portland State sample, which I administered under the direction of Dr. Alex Stepick, an invitation to participate was e-mailed to all undergraduate students. A lottery with two possible winners of a $\$ 250.00$ Visa gift card was offered as an incentive. The lottery winners were chosen by using a random number generator found on the internet, sampling without replacement, using the individual i.d. numbers of each survey. Slightly over 2,300 surveys were completed. Because many people fill out surveys randomly to have a chance at winning the incentive offered, we calculated the mean time taken to complete the survey and kicked-out any survey that was one standard deviation and a half below the mean time to observed for completion of the survey. As mentioned before, data were cleaned by replacing missing values with the mean score for said variable, if the missing values were below $15 \%$, which was the case for all but the Schwartz battery of individual values, where missing values ranged from $21 \%$ to $23 \%$, in which case the variables were left as they were (IBM 2020). See Appendix 2 for a copy of the survey.

The survey had been translated into English by a transcription and translation service in the UK. Since the survey was translated in England, a few minor changes had to be made to ensure accurate answers for American English-speakers. The first change was substituting "countryside" with "rural", as this is not a common term in America, and it was thought that it may be confusing. One further change was to add categories to the 
gender question. Dr. Stepick and I added LGBTQ terms such as non-binary, etc. Once edited, the survey was transferred to the Qualtrics survey platform on which it was administered to the PSU undergraduates.

The total number of surveys after cleaning was $(\mathrm{N}=1996)$, which in the spring of 2018, was roughly 10\% of the school's undergraduate population (Portland State University 2018). The average age of PSU students is 27 , and so was the mean age of PSU survey respondents. The survey also skews toward female, as only $469(26.4 \%)$ of the surveys were male, whereas 1040 were either female or non-binary etc. Women makeup around 56\% of the PSU student body. Thus, in terms of demographics, the survey captured a representative snapshot of the university student body.

\section{Data Analysis}

The responses from the PSU students, as well as the rest of the nations sampled were analyzed using SPSS statistics software. All the other nations survey data were collected, cleaned, and merged by the main YARG researchers in Finland. A copy from all nations, minus the Portland State sample, were emailed to us. The data we received was not in SPSS format and some of the variables in the received data from other samples were missing As a result of trouble in merging all twelve of the other survey data with the PSU data, some of the variables have missing data. The product of merging is a dataset that includes PSU responses alongside all the other nations to be analyzed as a whole. 


\section{Measuring Religiosity}

Measuring religiosity has always been a complicated problem, there are many problems associated with current attempts to measure religiosity. One of the main problems is that religion is measured in the US via telephone surveys. The two major polling and public opinion companies Pew and Gallup have conducted the majority of religious surveys.

Regarding Pew, Gallup, and ARIS data, the first problem is that people tend to lie about how religious they are, as measured by how often they attend religious ceremonies (Rossi and Scappini 2014). Many reasons for this tendency to overreport attendance are proffered, but scholars are still searching for an explanation. Another problem with measuring religiosity, whether it is over the phone, or especially via a written survey, is the wording of the question. One must be very delicate as to what one means by religiosity. For instance, a question may ask "How religious do you consider yourself to be?" This question seems straightforward, but a person who is privately religious (that is not officially belonging to a church or attending its rituals or social functions, yet very spiritual (for instance a Christian who prays at home but does not attend mass), may answer "highly" to the question. Surveys or telephone interviews need to specify whether they are asking about organized, as opposed to individual religiosity. Scholars of secularity often consider private religiosity to be on the spectrum of secularism, as opposed to a person who attends church

or Mosque services weekly (Baker 2015; Steve 2002; Brown 2012; Cassanova 1994; and Gorski 2008). 
Consequently, the religious questions in YARG are very explicit and are worded in such a way as to differentiate between private and public religiosity. The questions concerning religiosity occur early in the survey, and are likely to yield accurate results prior to survey fatigue setting in. YARG has six main religious questions (please refer to Appendix 2, questions B.8-B.13.). These six questions cover private religiosity, how religious a person's family was/is, how often they attend religious ceremonies, and a few other specific questions.

Finally, to make trends in the data easier to recognize, the respondent's Religiosity (B.10 How religious one rates one's self) was recoded into a new variable, "High/Low religion. Because the original variable was measured on a 11-point scale (0-10), I simply classified everyone who rated themselves as 0-5 as "Low" religiosity and those who answered 6-10 as "High" religiosity. 


\section{Chapter Four:}

\section{The Data: Religion and Values Among College Aged Youth}

. This chapter addresses Research Question 1, How secular versus religious are college youth, both at Portland State University and at the other universities in the 13 sampled countries? Table 4.1 indicates the sources of the samples for YARG. As mentioned above, all samples were taken at colleges. In some countries YARG was administered in different languages, such as both Arabic and Hebrew in the Israel sample. In those places where there were alternatives for different languages, respondents chose which language they took the survey in. Where the language is not indicated, the survey was in the dominant language of that country, such as English in the two U.S. samples.

Table 4.1

YARG Samples and Languages

\begin{tabular}{l|r|r|}
\hline & Frequency & Percent \\
\hline Canada (French) & 410 & 5.9 \\
\hline China & 325 & 4.7 \\
\hline Finland & 484 & 7.0 \\
\hline Ghana (English) & 420 & 6.0 \\
\hline India (Bengali) & 94 & 1.4 \\
\hline India (English) & 204 & 2.9 \\
\hline Israel (Arabic) & 429 & 6.2 \\
\hline Israel (Hebrew) & 332 & 4.8 \\
\hline Japan (English) & 324 & 4.7 \\
\hline Peru & 321 & 4.6 \\
\hline Poland & 299 & 4.3 \\
\hline Russia & 343 & 4.9 \\
\hline Sweden & 328 & 4.7 \\
\hline Turkey & 347 & 5.0 \\
\hline U.S. Private, Non- & 304 & 4.4 \\
Denominational & & \\
College & 1,995 & 28.7 \\
\hline U.S. Portland & & \\
\hline State University & 6,959 & 100.0 \\
\hline Total N & & \\
\hline Tale constris & & \\
\hline
\end{tabular}

(Table constructed by Dr. Stepick and Joseph Eichenlaub) 
The total number of combined surveys, including the Portland State sample is 6,962. Portland State is by far the largest sample with 1,996 valid surveys. The combined data lacks a nuanced variable for gender, and the sample is divided amongst male and female, with 2,932 Females and 1,938 males. The female to male ratio is almost 2:1.

The overall YARG sample mean age is 22.58 years old. This makes the sample in keeping with the average college student in the US, which is age 18-24 (Educationdata.org 2019). In terms of income, not surprisingly the mean category of family income was "somewhat higher than average," considering these are college students in differing parts of the globe, where college loans and grants are not readily available, this result makes sense. The YARG survey has a short demographic section, as mentioned prior in the paper, the preceding snapshot of the data, gives us a picture of young, mostly females, who were raised in the suburbs, and come from families with "higher than average wealth. 


\begin{tabular}{|l|c|c|c|c|c|}
\hline \multicolumn{5}{|c|}{ Tabic Demographics of All Nations } \\
\hline & $\begin{array}{l}\text { Female } \\
\text { (Percent) }\end{array}$ & $\begin{array}{l}\text { Male } \\
\text { (Percent) }\end{array}$ & $\begin{array}{l}\text { Income } \\
\text { Much Lower } \\
\text { than Average } \\
\text { (Percent) }\end{array}$ & $\begin{array}{l}\text { Income } \\
\text { Much Higher } \\
\text { than Average } \\
\text { (Percent) }\end{array}$ & $\begin{array}{l}\text { Age } \\
\text { (Mean) }\end{array}$ \\
\hline $\begin{array}{l}\text { Canada } \\
\text { (French) }\end{array}$ & 70.4 & 29.6 & 18.8 & 6.3 & 20.1 \\
\hline China & 55.3 & 44.7 & 1.8 & 3.2 & 19.6 \\
\hline Finland & 65.7 & 64.3 & 18.8 & 4.5 & 20.4 \\
\hline $\begin{array}{l}\text { Ghana } \\
\text { (English) }\end{array}$ & 48.0 & 52.0 & 13.3 & 5.1 & 21.8 \\
\hline India (Bengali) & 44.6 & 45.3 & 53.3 & 0.0 & 22.4 \\
\hline India (English) & 65.6 & 64.4 & 53.3 & 5.1 & 22.3 \\
\hline $\begin{array}{l}\text { Israel } \\
\text { (Palestinian) }\end{array}$ & 55.3 & 54.7 & 11.5 & 5.5 & 20.9 \\
\hline Israel Hebrew & 56.0 & 44.0 & 8.8 & 12.8 & 24.3 \\
\hline $\begin{array}{l}\text { Japan } \\
\text { (English) }\end{array}$ & 39.6 & 59.4 & 8.2 & 2.0 & 19.7 \\
\hline Peru & 38.3 & 61.7 & 17.1 & 3.9 & 20.2 \\
\hline Poland & 58.0 & 42.0 & 11.9 & 8.6 & 21.4 \\
\hline Russia & 63.8 & 36.2 & 3.9 & 7.5 & 20.1 \\
\hline Sweden & 70.0 & 30.0 & 6.0 & 5.8 & 19.6 \\
\hline Turkey & 68.0 & 32.0 & 3.9 & 5.1 & 21.1 \\
\hline $\begin{array}{l}\text { US Religiously } \\
\text { Affiliated } \\
\text { College }\end{array}$ & 54.9 & 44.1 & 8.6 & 15.4 & 20.3 \\
\hline $\begin{array}{l}\text { USA Portland } \\
\text { State } \\
\text { University }\end{array}$ & $* 52.1$ & $* 23.5$ & 23.8 & 4.9 & 26.8 \\
\hline & & & & & \\
\hline
\end{tabular}

(Table constructed by Dr. Stepick and Joseph Eichenlaub) * The male and female categories do not equal $100 \%$ in the PSU sample, because in our version of YARG we added non-binary gender categories such as LGBTQ.

The survey question on religiosity asks students how they rate their own religiosity on a scale from " 0 " not at all religious, to " 10 " very religious. Not surprisingly, Portland State's mean measure of religiosity, was low at 3.16 out of a possible ten. This result seems in keeping with the literature regarding the Pacific Northwest and secularism. The survey separately, asked "How religious was the family you grew up in?" The Portland State mean for what we call "Family Religiosity" was 
slightly higher, with a mean of 5.33. Many collegiate age young adults often experiment with "finding themselves" and may tinker with individual values. and religious one is as well (Freitas 2015; Ueker et.al 2007; Baker 2015).

Compared to the overall YARG samples self-reported Religiosity, PSU is not as distinctive as the literature on religion in the Northwest led us to expect. The mean score on self-measured Religiosity for the samples of all 13 nations combined is 3.70 , just slightly higher than the Portland State sample. The Portland State sample in fact overall reported being more religious, than not only the lowest, Sweden, at 2.04, but Portland State is also more religious than Russia and Canada, and only slightly lower than in the U.S. Religiously Affiliated College sample (See Table 4.2). The most religious sample was Ghana with a mean of 6.78 .

In almost all YARG samples, the respondents on average rated their Family Religiosity higher than their own, although often only slightly. For instance, the Israeli Arabic (likely Palestinian) sample's self-rated religiosity was 5.03, while they measured their family at 6.06 , almost a full point higher. Ghana has the highest self-measured religiosity (6.38), and the highest family religiosity also, with a mean of 7.19. On the low end the differences become slightly more pronounced. For example, students in Sweden, the least religious sample at 2.04 of self-measured religiosity, rated their family's religiosity at 4.65 , slightly twice what they rate themselves. The Portland State sample is like Sweden, in that self-measured religiosity is 3.12 , while the respondent's rate their families at 5.31, again, about twice as high. 


\begin{tabular}{|c|c|c|}
\hline \multicolumn{3}{|c|}{$\begin{array}{c}\text { Table } 4.3 \\
\text { Religiosity of Self and Family by Nation } \\
\text { Means of 0-10 Scale }\end{array}$} \\
\hline & $\begin{array}{l}\text { Self-Reported } \\
\text { Religiosity }\end{array}$ & Family Religiosity \\
\hline Canada & 2.79 & 4.33 \\
\hline China & 3.63 & 4.38 \\
\hline Finland & 3.54 & 3.82 \\
\hline Ghana & 6.38 & 7.19 \\
\hline India (Bengali) & 4.38 & 5.86 \\
\hline India (English) & 4.63 & 5.90 \\
\hline Israel (Arabic) & 5.03 & 6.06 \\
\hline Japan & 4.15 & 4.34 \\
\hline Peru & 3.95 & 5.97 \\
\hline Poland & 4.51 & 6.17 \\
\hline Russia & 2.73 & 4.61 \\
\hline Sweden & 2.04 & 4.65 \\
\hline Turkey & 4.33 & 5.73 \\
\hline $\begin{array}{l}\text { U.S. Religiously } \\
\text { Affiliated College }\end{array}$ & 3.37 & 5.31 \\
\hline $\begin{array}{l}\text { Portland State } \\
\text { University }\end{array}$ & 3.12 & 5.33 \\
\hline
\end{tabular}

(Table constructed by Dr. Stepick and Joseph Eichenlaub

To gain further insight, and for the subsequent logistic regression in the following chapter, I created a new variable called "Hi/Lo religion". This variable was created simply by dividing the $0-10$ sample in the middle at 5 . Everyone who reported 5 or lower was recoded into Low Religiosity and 5 and above as High Religiosity as reported in Table 4.4. When examining trends of religiosity or irreligiosity, a binary variable made it easier to spot trends in the data. In short, the binary variable allowed for distribution of religion to present itself much more clearly. Here we can see that apart from Ghana, in every sample fewer than 50 percent are highly religious. Ghana has over 70 percent who are highly religious and the next closest is Arabic speaking Israelis at just over 40 percent. The overall percentage for all samples was just under 30 percent $(29.14 \%)$ who rate themselves as 
highly religious. In short, worldwide (or more precisely in these samples representing 13 different countries) college students are not very religious. Portland State is less religious than the overall sample (77.69\% not religious compared to $70.13 \%$ overall), but it remains slightly more religious than not only Sweden and Russia, but also the French-speaking Canadian sample and the Chinese sample. Again, Portland State Students are highly secularized, but in a cross-national perspective, not as secular as some might expect.

\begin{tabular}{|c|c|c|}
\hline Nation & $\begin{array}{l}\text { Low to } \\
\text { non- } \\
\text { religious } \\
\text { (Percent) }\end{array}$ & $\begin{array}{l}\text { Highly } \\
\text { Religious } \\
\text { (Percent) }\end{array}$ \\
\hline Canada (French) & $80.7 \%$ & $19.3 \%$ \\
\hline China & $69.2 \%$ & $30.8 \%$ \\
\hline Finland & $67.9 \%$ & $32.1 \%$ \\
\hline Ghana (English) & $28.5 \%$ & $71.5 \%$ \\
\hline India (Bengali) & $59.5 \%$ & $40.5 \%$ \\
\hline India (English) & $67.6 \%$ & $32.4 \%$ \\
\hline Israel (Arabic) & $57.8 \%$ & $42.2 \%$ \\
\hline Israel (Hebrew) & $72.8 \%$ & $27.2 \%$ \\
\hline Japan (English) & $68.2 \%$ & $31.8 \%$ \\
\hline Peru & $69.4 \%$ & $30.6 \%$ \\
\hline Poland & $60.5 \%$ & $39.5 \%$ \\
\hline Russia & $79.6 \%$ & $21.4 \%$ \\
\hline Sweden & $57.5 \%$ & $52.5 \%$ \\
\hline Turkey & $53.0 \%$ & $47.0 \%$ \\
\hline USA Religiously Affiliated College & $74.0 \%$ & $35.0 \%$ \\
\hline Portland State University & $77.6 \%$ & $22.3 \%$ \\
\hline Total N & 4,888 & 2,028 \\
\hline
\end{tabular}

(Table constructed by Dr. Stepick and Joseph Eichenlaub)

In short, the data indicate that the answer to research question one is, that what emerges from this data is that almost all national samples are not highly religious. In addition, every sample rated their family as being more religious than they, themselves 
were even the samples that were at the low-end of the spectrum follows this trend. Most of the sample of college aged youth are not deeply religious, except for a few samples, and that these students are less religious than their families. 


\section{Chapter Five:}

Values of Individuality, Religiosity and Cosmopolitanism: Religion and Volunteerism.

\section{Values of College Age Youth}

This Chapter addresses research question 2: Will the sample's college youths' values, tend towards individualism, as opposed to more conservative values and cosmopolitan humanitarian values? Increasing secularity among post-industrial societies has left many scholars asking what values college age youth hold, if not values inherited from religious institutions or their respective families? To answer this question, I compiled the mean score of the overall sample for each Schwartz value. I also created three broader categories of Schwartz values: individual, conservative, and cosmopolitan/humanitarian.

One of the key aspects of the YARG survey is to measure not simply religiosity, but religiosity in comparison to other values more broadly. Table 5.1 reports each nation's mean score on each Schwartz value, grouped into the categories: individual, conservative, and cosmopolitan/humanitarian. Recall that each Schwartz value is rated from, "1 Not at all like me", to "6", "Very much like me."

Individualism is expressed by four values: Self-Direction, Stimulation, Hedonism, and Achievement. The mean scores for each of these individual values are at least 4.0 or higher, with Self-Direction's mean score being the highest at 5.0. A simple conclusion is that these samples of college youth are indeed individualistic. 
As reported in Table (5.1). The Finns have the highest self-direction (5.9), followed by the English-speaking India sample (5.7) and the Hebrew-speaking Israeli sample (5.7), while the Japanese sample is the lowest (4.3). Portland State (4.9) is just below the overall mean. Both Stimulation and Hedonism, which some may consider the epitome of selfcentered, individualistic values, have lower overall means (4.4 and 4.7 respectively) than both Benevolence and Universalism (5.1 and 4.8 respectively). Turkey incidentally is the highest on both Stimulation and Hedonism, while Portland State (4.3 and 4.7) is slightly below or at the overall means of these two.

One might expect university students to be focused on Achievement. However, all the samples rate lower on Achievement than on Self-Direction, which one also might conceive as consistent with a university education. In comparing the higher scores from the thirteen nations in the study, on Self-Direction and Achievement, it appears as if these university students are more focused on the inner rewards of education that promote SelfDirection; than the external ones marked by Achievement. This is further confirmed by one of the variables categorized as Conservative, viz. Power. Power had the lowest mean scores, both for the overall sample and for each individual sample.

Despite these individualistic values, these university students cannot be said to be solely individualistic. They score above the mid-point (3.0 on the 0-6-point scale) on average for the Conservative values i.e., Conformity, Tradition, Security, and Power. The only partial exception, as mentioned above is Power, which overall is just above the midpoint, at 3.1 and for which a few samples are below 3.0 (French-speaking Canadians, Finns, Japanese, Poles, and Portland State). Of the conservative values, Conformity and 
Security are judged the most important with the overall means of each being 4.7. Tradition is less likely to be judged important, although variation expresses itself across the samples with tradition being the highest for Ghana at 4.6. As indicated in the last chapter, Ghana is also the highest in religiosity. The lowest are the Swedes (2.5) who were also the lowest on Religiosity. Portland State at 3.6 is just below the overall mean of 3.8. Conformity is perhaps the Conservative value that prima facie contradicts the statement that these university students are utterly individualistic. The overall mean on Conformity is the same as Hedonism and not dramatically lower than Self-Direction (4.7 for Conformity versus 5.0 for Self-Direction). Ghana at 5.7 is again the highest in this Conservative value, while Portland State at 4.6 is just below the mean. We could conclude that in general the students in the sample from the thirteen nation YARG study have contradictory values, viz. between Self-Direction and Conformity, or perhaps they view themselves as Self-Directed compared to the broader society and elder generations and are in Conformity with their peers.

Most relevant to this thesis are the Cosmopolitan-Humanistic values, especially as they compare to the Individualistic values. The two Schwartz values in this category, Benevolence and Universalism, have the highest overall means (5.1 and 4.9 respectively) of all 10 values, apart from Self-Direction (5.0). The Bengali-speaking India sample is the highest in each of these, while the lowest is Japanese. In short, the answer to research question 2 the data indicates that these samples are considerably more CosmopolitanHumanitarian than they are Conservative, especially in terms of the Conservative values of Tradition and Power. At the same time, they express a Self-Direction without being 
extraordinarily self-centered. The next section examines the relationship between Cosmopolitan-Humanitarian values and religion more closely. 


\begin{tabular}{|c|c|c|c|c|c|c|c|c|c|c|}
\hline \multicolumn{11}{|c|}{ Table 5.1 Mean Scores for Schwartz Values } \\
\hline & \multicolumn{4}{|c|}{ Individual Values } & \multicolumn{4}{|c|}{ Conservative Values } & \multicolumn{2}{|c|}{$\begin{array}{c}\text { Cosmopolitan-Humanitarian } \\
\text { Values }\end{array}$} \\
\hline $\begin{array}{l}\text { Country \& } \\
\text { Language }\end{array}$ & $\begin{array}{c}\text { Self- } \\
\text { Direction }\end{array}$ & Stimulation & Hedonism & Achievement & Conformity & Tradition & Security & Power & Benevolence & Universalism \\
\hline $\begin{array}{l}\text { Overall } \\
\text { Means }\end{array}$ & 5.0 & 4.4 & 4.7 & 4.0 & 4.7 & 3.8 & 4.7 & 3.1 & 5.1 & 4.8 \\
\hline $\begin{array}{l}\text { Canada } \\
\text { French }\end{array}$ & 5.2 & 4.4 & 5.5 & 4.3 & 4.3 & 3.3 & 4.3 & 2.6 & 5.5 & 4.2 \\
\hline Finland & 5.9 & 4.3 & 4.2 & 3.4 & 4.2 & 3.2 & 4.6 & 2.3 & 4.5 & 4.8 \\
\hline Ghana & 4.8 & 4.1 & 4.3 & 4.7 & 5.7 & 4.6 & 5.2 & 3.3 & 5.5 & 4.6 \\
\hline $\begin{array}{l}\text { India } \\
\text { Bengali }\end{array}$ & 4.9 & 4.2 & 4.3 & 4.1 & 4.1 & 4.3 & 5.8 & 3.5 & 5.7 & 5.1 \\
\hline $\begin{array}{l}\text { India } \\
\text { English }\end{array}$ & 5.7 & 4.6 & 4.6 & 4.3 & 4.1 & 4.6 & 5.1 & 3.8 & 5.2 & 5.5 \\
\hline $\begin{array}{l}\text { Israel } \\
\text { Arabic }\end{array}$ & 5.2 & 4.2 & 5.8 & 4.5 & 5.2 & 4.4 & 5.7 & 3.5 & 5.2 & 4.9 \\
\hline $\begin{array}{l}\text { Israel } \\
\text { Hebrew }\end{array}$ & 5.7 & 4.2 & 4.3 & 4.8 & 5.2 & 3.1 & 5.6 & 3.9 & 5.5 & 4.9 \\
\hline
\end{tabular}

*Table continues on page 56 


\begin{tabular}{|c|c|c|c|c|c|c|c|c|c|c|}
\hline & \multicolumn{4}{|c|}{ Individual Values } & \multicolumn{4}{|c|}{ Conservative Values } & \multicolumn{2}{|c|}{$\begin{array}{l}\text { Cosmopolitan-Humanitarian } \\
\text { Values }\end{array}$} \\
\hline $\begin{array}{l}\text { Country \& } \\
\text { Language }\end{array}$ & $\begin{array}{c}\text { Self- } \\
\text { Direction }\end{array}$ & Stimulation & Hedonism & Achievement & Conformity & Tradition & Security & Power & Benevolence & Universalism \\
\hline Japan & 4.3 & 3.6 & 4.7 & 3.3 & 3.2 & 3.6 & 3.7 & 2.6 & 3.1 & 3.2 \\
\hline Peru & 5.2 & 4.6 & 4.3 & 4.5 & 4.6 & 3.1 & 4.7 & 2.5 & 5.0 & 4.8 \\
\hline Poland & 4.9 & 4.7 & 4.4 & 3.4 & 4.3 & 3.5 & 4.1 & 2.1 & 5.2 & 4.2 \\
\hline Sweden & 5.1 & 4.3 & 4.7 & 3.9 & 4.7 & 2.5 & 4.6 & 3.2 & 5.4 & 4.1 \\
\hline Turkey & 5.3 & 5.6 & 5.4 & 4.1 & 5.1 & 4.1 & 5.1 & 3.6 & 5.3 & 5.0 \\
\hline $\begin{array}{l}\text { U.S. } \\
\text { Religiously } \\
\text { Affiliated } \\
\text { College }\end{array}$ & 4.9 & 4.6 & 4.9 & 3.7 & 4.8 & 3.6 & 4.4 & 3.0 & 5.1 & 4.8 \\
\hline $\begin{array}{l}\text { Portland } \\
\text { State } \\
\text { University }\end{array}$ & 4.9 & 4.3 & 4.7 & 3.8 & 4.6 & 3.6 & 4.4 & 2.9 & 5.0 & 5.0 \\
\hline
\end{tabular}




\section{Cosmopolitanism-Humanitarianism and Religion}

How does a students' religiosity relate to the degree to which they are cosmopolitan/Humanitarian? To address this question. I conducted a linear regression, employing Universalism (my proxy indicator for cosmopolitanism-humanitarianism) as the dependent variable, with self-measured Religiosity (B.10) as the main independent variable. I also include a limited list of control variables, and Stimulation, one of the Schwartz values, as a mediating variable.

I employ one of Schwartz's universal 10 values to act as a mediating variable in the first regression. Stimulation is defined by Schwartz as, excitement, novelty, and challenge in life (Schwartz 1992). There is no direct correlation in any literature on Schwartz's value of stimulation and religion. However, I expect that higher levels of Stimulation lead to higher levels of Universalism within this particular sample. Stimulation relates to novelty, excitement, and challenge in life, what is more exciting or challenging than discovering, learning about, and embracing other cultures? Stimulation embodies values that make it more likely for one to possess an attitude of acceptance an openness to cultures other than one's own, therefore making Stimulation a great variable to explore a possible mediating effect in this regression. The real question is, does religion influence either of these values? Does religion increase or decrease Stimulation, and ergo, Universalism? Table 5.2 reports the descriptive statistics in this linear regression, along with those used in the regression predicting Volunteerism presented in the next section. 


\begin{tabular}{|l|c|c|c|}
\hline \multicolumn{5}{|c|}{$\begin{array}{c}\text { Table 5.2 } \\
\text { Descriptive Statistics: } \\
\text { All Variables in Both Regressions: } \\
\text { N=4,896) }\end{array}$} \\
\hline & $\begin{array}{c}\text { Means and } \\
\text { Percentages }\end{array}$ & SD & Range \\
\hline Religiosity & 3.7 & 2.98 & $(0-10)$ \\
\hline $\begin{array}{l}\text { Religiosity of } \\
\text { Family }\end{array}$ & 5.2 & 2.68 & $(0-10)$ \\
\hline Age (Control) & 22.58 & 3.36 & $(17-76)$ \\
\hline Gender (Control) & & & \\
\hline Female & $72.2 \%$ & & \\
\hline Male & $27.8 \%$ & & \\
\hline Non-Binary & $30 \%$ & & \\
\hline Income (Control) & 2.91 & 1.16 & \\
\hline $\begin{array}{l}\text { Much Lower Than } \\
\text { Average }\end{array}$ & $14.2 \%$ & & \\
\hline Somewhat Lower & $18.3 \%$ & & \\
\hline About Average & $29.0 \%$ & & \\
\hline Somewhat Above & $24.8 \%$ & & \\
\hline Much Above & $9.7 \%$ & & \\
\hline $\begin{array}{l}\text { Stimulation } \\
\text { (Mediation) }\end{array}$ & 4.36 & 0.13 & \\
\hline
\end{tabular}

(Table constructed by Dr. Stepick and Joseph Eichenlaub)

A stepwise linear regression was presented in table 5.3 and was conducted including all nations in the sample with a large percentage of the data $(70.3 \%)$. Some of the respondent's answers are not present because of missing data in the samples. The DV is Universalism (the proxy for Cosmopolitanism/Humanitarianism or $\mathrm{CH}$ for short), with Religiosity as the IV. The regression was conducted in three stepwise models each predicting Universalism: the first model simply has Religiosity regressed against $\mathrm{CH}$; the second model adds the control variables; and, the third model includes the mediating variable, Stimulation. The regression has an ( $\mathrm{N}$ of 4,896).

Religion tends to have a "world-shrinking" effect, it creates and as such creates a parochial outlook (Turner 2020). In sum, Cosmopolitanism is seen by scholar of Secularization as having an effect of making religion less salient, as people's cosmopolitan 
outlook rises. Ergo, if a person has high religiosity, they too should have less of a cosmopolitan world outlook within this sample.

Model 1 with the Universalism (DV) regressed against Religiosity, yielded a B value of 0.16 , which was statistically significant. With every one-unit increase in a student's religiosity, their cosmopolitanism/universalism increases by 0.16 (Table 5.3, Model 1).

This relationship is statistically significant $(\mathrm{p}<0.001)$. This result indicates that religion has a positive, yet minor effect on one's score on $\mathrm{CH}$.

This section addresses Research Question 3a: Does students' religiosity still relate to cosmopolitanism/universalism, after controlling for related factors Age, Gender Income and Religiosity, so I control on those factors to achieve a better estimate of how religiosity relates to volunteering and $\mathrm{CH}$. The age variable was significant, but with a very low coefficient with a B of $.02(\mathrm{P}<0.001)$. As for gender, it was females who were slightly higher on $\mathrm{CH}$, and have a higher score on Religiosity. The B for Gender was -.032, as women are coded as 1 , and men coded as 0 , this indicates that women are likelier to have a higher level of $\mathrm{CH}$ than men. Income is the next control variable in model 2 , which is observed at B -0.07 , which indicates that as one's income declines (very slightly) one's score on Universalism also declines. The positive relationship between a student's religiosity and $\mathrm{CH}$ is still evident even after adjusting for related factors (Table 5.3, Model). In model 3 I address research question 3b: Is the relationship between students' religiosity and Cosmopolitanism/Humanitarianism partially mediated (i.e., explained) by differences in stimulation? Stimulation is used in model 3, which yields a B of 0.29. 
Because the student religiosity coefficient decreases from Model 2 to Model 3 in Table 5.3. The short answer to research question $3 \mathrm{~b}$ suggests that the positive relationship between student religiosity and $\mathrm{CH}$ is partially mediated/explained by stimulation.

The results of the linear regression model seem to indicate that $\mathrm{CH}$ has truly little impact on religion. This result is not surprising, as the entire sample's mean score on selfmeasured Religiosity (B.10) was 3.70 on a 1-10 Likert scale. With this largely secular sample it is not surprising that $\mathrm{CH}$ is little effected by religiosity. This section addressed research question 3 and found that the evidence supports a conclusion that $\mathrm{CH}$ impacts neither values of religion nor stimulation. With regards to today's young people, values that include others, and favor stimulation, do not seem to be affected by religion almost at all. 
Table 5.3

Cosmopolitanism/Humanitarianism Predicted by Religiosity Linear Regression

\begin{tabular}{|c|c|c|c|c|c|c|}
\hline & \multicolumn{2}{|c|}{ Model 1 - Baseline } & \multicolumn{2}{|c|}{$\begin{array}{l}\text { Model } 2 \text { - Adjusted } \\
\text { by Controls }\end{array}$} & \multicolumn{2}{|c|}{ Model 3 Mediation } \\
\hline & $\operatorname{Exp}(\mathrm{B})$ & SE & $\operatorname{Exp}(\mathrm{B})$ & SE & $\operatorname{Exp}(B)$ & SE \\
\hline Religiosity & $0.16^{* * *}$ & $(0.00)$ & $0.03 * * *$ & $(0.00)$ & $0.01 * *$ & $(0.00)$ \\
\hline Age & & & $0.02 * * *$ & $(0.03)$ & $0.29 * * *$ & $(0.00)$ \\
\hline Gender & & & $-0.32 * * *$ & $(0.10)$ & $-0.31 * * *$ & $(0.02)$ \\
\hline Income & & & $-0.07 * * *$ & $(0.01)$ & $-0.08 * * *$ & $(0.00)$ \\
\hline Stimulation & & & & & $0.29 * * *$ & $(0.10)$ \\
\hline Constant & 4.95 & & 4.62 & & 3.19 & \\
\hline
\end{tabular}

Respondents (n) 4,869

$+\mathrm{p}<0.10, * \mathrm{p}<0.05, * * \mathrm{p}<0.01, * * * \mathrm{p}<$

0.001 .

(Table constructed by Dr. Stepick and Joseph Eichenlaub) 


\section{Volunteering and Religion}

Research Question 4, How does a students' religiosity relate to whether they volunteered in the last year? Is addressed in this chapter. A simple manner of measuring values of young people lies in asking whether they volunteer to help people in their community. As mentioned in the literature review (Ammerman 2005; Unruh and Sider 2005; Wilson 2000), volunteering can be a value that demonstrates a person has a good moral compass, that they are not completely self-focused. The YARG sample offers us a great chance to empirically determine if religion plays a substantial role in morality, at least indicated by volunteering. As well as YARG the literature review informs us that family religiosity does play a positive role in the volunteering posture of young people. Since the majority of the respondent's claimed that their family had higher religiosity than they currently possessed, it seems that this variable would add a positive mediating effect. In short, if the family you grew up in is more religious than you are currently it seems to reason, based on the religion that a young person in this cross-national sample would also be more likely to volunteer.

What this final regression model attempts to answer is: Does religion have a direct effect on whether a person has volunteered within the last year? I carried out a logistic regression with Volunteering as the main DV, and Religiosity as the main IV. I used the same control variables as in the linear regression for cosmopolitanism.

Additionally, Volunteering was recoded into a dummy variable. The question from YARG asks, "In the past year have you volunteered to help someone other than your family and close relatives, done something good for other people, or done charity work? The 
Volunteering is measured on a 5-point Likert-type scale, with the options "yes", "probably yes", "probably not", "no", and "I do not know". In recoding, the "I don't know" answers were discarded, and a simple dummy variable was created with "definitely" and "probably yes" equaling " 1 ," and "probably no" and "no" equaling zero. Unlike the regression for Cosmopolitanism, another mediating variable was used. In this model I used a second religiosity variable, Family Religiosity, (B.11 YARG), which is measured by the question, "How religious would you say the family you grew up in was?" Family Religiosity is measured on the same 0-10-point scale as an individual's Religiosity where " 0 " equated with "Not at all religious" and "10" corresponding to "Very religious. The target group for this regression was " 1 " or having volunteered in the past year.

Table 5.4 presents the results. Model 1 consists of the Volunteering dummy and a respondent's Religiosity, i.e., how religious a respondent rated themselves as being. The second step includes the control variables, Age, Income, and Gender. The third and final step adds the mediating variable Family Religiosity, i.e., how religious was the family a respondent grew up in. The reasoning behind adding a family's religion is that even though a college age youth might rate themselves as not religious, their family may very well have been so. Despite not rating one's self as religious, it seems likely that some of the base moral teachings of organized religion may still be a part of the respondent's value system, without a deity. I hypothesized that Family Religiosity would have a strong mediating effect on whether a person volunteered or not.

As with the linear regression on cosmopolitanism, a respondent's religiosity appears to have little influence on whether they volunteered in the last year. Model $1 \mathrm{~B}$ was 
0.16 with regards to the target group of volunteering. Although this coefficient is positive, it is small, indicating that religion plays a small but positive role in whether one volunteered in the past year or not. With every one-unit increase in a student's religiosity, the log odds of volunteering increase by 0.068 (Table 5.4, Model 1). This relationship is statistically significant $(\mathrm{p}<0.001)$.

Moving forward with model 2, a respondent's Age has a coefficient of B $0.02^{* * *}$, reflecting that a person's age, in this sample has a statistically significant positive, but small, effect on the likelihood of volunteering. Gender's coefficient is $.291^{* * *}$, again positive and notably higher. With females coded as 1 , this indicates that women are more likely to have volunteered than men. Moreover, the coefficient for Gender rose slightly as the model included more variables. The positive relationship between a student's religiosity and volunteering is still evident even after adjusting for related factors (Table 5.4, Model 2).

Regarding Research Question 4a: Does students' religiosity still relate to volunteering, after controlling for related factors? The next variable in the locus of controls is Income, the same variable as used in the linear regression above. The target group for this variable is "much lower than average". The coefficients for this grouping are somewhat bell-shaped. The coefficients begin at 0.39 for "much lower than average" to .045 for "somewhat lower than average". Followed by a B of 0.37 for "about average", and back down again for "somewhat and higher than average", both at 0.21 . Unfortunately, none of the income variables were statistically significant, therefore no conclusions can be drawn from them. 
Finally, the mediating variable was added to the model. The mediating variable in this case is "How religious was the house you grew up in?". The Coefficient for this variable is $0.084 * *$. This result indicates a very slight mediating effect. Because the student religiosity coefficient decreases from Model 2 to Model 3 in Table 5.4, and is no longer statistically significant, results suggest that the answer to research question $4 \mathrm{~b}$ is a positive relationship between student religiosity and volunteering is partially mediated/explained by family religiosity.

The data regarding research question 4: how does a students' religiosity relate to whether they volunteered in the last year? Yielded two main results. One, that women are more likely than men to have volunteered in the past year. There could be a whole host of reasons why this might be, such as normative "care-giving" behavioral roles expected from women. Since this is a multi-nation study and normative behavior for men in Sweden as opposed to Ghana are more than likely quite different. The second main finding is that how religious a person's family in which they grew up in, does influence volunteering. This result seems to indicate my hypothesis that the moral teachings of a religion may stick with someone, even though the religious practices and beliefs do not. 
Table 5.4

Volunteerism Regressed Against Religiosity

\begin{tabular}{|c|c|c|c|c|c|c|}
\hline & \multicolumn{2}{|c|}{ Model 1 - Baseline } & \multicolumn{2}{|c|}{$\begin{array}{c}\text { Model } 2 \text { - Adjusted by } \\
\text { Controls }\end{array}$} & \multicolumn{2}{|c|}{ Model 3 Mediation } \\
\hline & $\operatorname{Exp}(B)$ & (SE) & $\operatorname{Exp}(B)$ & (SE) & $\operatorname{Exp}(B)$ & (SE) \\
\hline How Religious & $0.068 * * *$ & $(0.02)$ & $0.064 * * *$ & $(0.02)$ & 0.03 & $(0.02)$ \\
\hline Age & & & $.047^{* * *}$ & $(0.01)$ & $.050 * * *$ & $(0.01)$ \\
\hline \multicolumn{7}{|l|}{ Gender } \\
\hline Male & & & $\begin{array}{l}\text { Ref } \\
\text { Group }\end{array}$ & RG & RG & RG \\
\hline Female & & & $.291 * * *$ & $\begin{array}{c}- \\
(0.09)\end{array}$ & $.317^{* * *}$ & $\begin{array}{c}- \\
(0.09)\end{array}$ \\
\hline \multicolumn{7}{|l|}{ Income } \\
\hline Ref Group Much lower than average & & & $\begin{array}{l}\text { Ref } \\
\text { Group }\end{array}$ & RG & RG & RG \\
\hline Much lower than average & & & 0.39 & $(0.18)$ & 0.38 & $(0.18)$ \\
\hline Somewhat lower than average & & & 0.45 & $(0.16)$ & 0.42 & (0.16) \\
\hline About Average & & & 0.37 & $(0.16)$ & 0.34 & (0.16) \\
\hline Somewhat above average & & & 0.21 & $(0.16)$ & 0.20 & $(0.02)$ \\
\hline Much above average & & & 0.21 & $\begin{array}{c}- \\
(0.15)\end{array}$ & 0.20 & $\begin{array}{c}- \\
(0.15)\end{array}$ \\
\hline Family religiosity & & & & & $.084^{* *}$ & $(0.00)$ \\
\hline Constant & 4.62 & & -0.08 & & & \\
\hline
\end{tabular}




\section{Chapter Six}

\section{Conclusions, Implications and Recommendations}

This thesis addressed four main questions not found in the current literature on secularism and young people.

- How secular versus religious are college youth, both at Portland State University and at the other universities in the 13 countries sampled?

- Will these college youths' values, tend towards individualism, as opposed to more conservative values and or cosmopolitan-humanitarian values?

- Will young people retain moral values, as measured by a linear regression of religiosity and whether young people have volunteered to help others within the last year?

- Will religiosity have an impact on young people who have a cosmopolitan world outlook, as measured by a comparable variable in Schwartz's basic individual values?

First, apart from Ghana, these university students are secular, as measured by their self-evaluation of Religiosity. Moreover, within this cross-national set of samples, Portland State students are secular, but not more so than most other university samples. In fact, Portland State University students are more religious than those in Sweden and Russia.

The relationship among individual, conservative, and Cosmopolitan/Humanitarian values is not straightforward with one set of values dominating the other two types. Based 
on the findings from this research, young people, religiosity, and personal values who have attended universities in 13 different countries tend to be highly individualistic and yet not solely self-centered or without morals that concern the welfare of others. This may seem like a contradiction, but it may point towards a conclusion that young people consider themselves individualistic, while inhabiting and displaying Cosmopolitan-Humanitarian values along with some Conservative values, particularly Security. This provides evidence that the logic of individualism that is built into neoliberal ideology is alive and well. Secondly, this evidence points toward a conclusion that young people value whatever norms are present within their respective societies, allowing them to express their individualism, within its prescriptive confines. One could think of this dynamic in terms of Adorno and Horkheimer's work in Dialectic of Enlightenment (1982) where they examine the culture of consumption, and what one consumes, as an ethic of the age, and what defines one as an individual. Individualism remains within certain boundaries, tacitly approved by the community, whether macro or micro-level, to which one belongs. True, absolute individuality is not likely to be completely tolerated, as individuality in a true sense would likely be disruptive to social norms (e.g., street artists, hobos' eccentrics etc.), as these groups often break so far from the norms of society in such a clear manner.

The logistic regression results clearly show that Religiosity, net of the controls, Age, Gender, and Income, has little effect on the likelihood of whether a respondent had high levels of cosmopolitan-universalist values. This is not surprising, as college students tend to come from families with slightly to very above normal incomes, especially in nations with inequality that is greater than even our own (Zimmer 2016). Moreover, universities worldwide tend to be based on the Western model which includes a humanistic 
and social science perspective (Inglehart 2018). The YARG sample is comprised of $53.8 \%$ of respondents who characterize their income as "about average" or "somewhat above average." This finding may indicate that in the age of mass communication, the internet, and especially social media, aspects of consumerism and cosmopolitanism such as accepting difference and honoring, rather than denigrating other cultures may be learned more from social media and the internet, or through a K-12 education, as opposed to student's family's immediate communities or religion (McEwan, B \& Denton M. 2011; M Denton, 2016). Religion played next to no part in influencing the Universalism coefficient. It appears that, while some are clearly religious, our new global media environment is working to create a more globally open youth (having access, largely through the internet/social media to all, or most corners of the globe) in this researcher's opinion.

Finally, the regression concerning volunteering demonstrates that Religiosity has little influence on whether those in this sample volunteered within the past year. The regression shows that even with the mediating variable of parents' religiosity, religion played little role in whether someone volunteered within the last year, therefore lending credence to the idea that young people still hold moral values without religion. A host of reasons may explain this, but as mentioned in the literature review, Lim, and MacGregor (2012) theorize that circles of friends, whether religious or secular can have a direct influence on volunteering, and this is likely the reason. Fewer people are involved with religion, meaning fewer children being brought up religious, which indicates a social network of friends who volunteer, but perhaps not because of religion but out of a sense of duty to mankind. 
In summation, secularism appears high amongst college-age youth around the world. These college youth are moral in several ways: they volunteer, and they have a cosmopolitan outlook on the world, and they are accepting of outsiders. Young people are highly individualistic, but with the caveat that it is an individualism that values and acts positively toward others.

\section{Limitations}

There are several limitations regarding all three areas of concentrated study within this thesis. I will address the limitations of both regression scenarios first and then move onto the comparison of values of individualism and conservatism, and cosmopolitanismhumanitarianism. While these limitations exist, I stand firmly behind the validity of these conclusions. The conclusions in this thesis will hopefully add to social scientific knowledge of the field of secularism, and values of young people.

College students in the United States and elsewhere, far too often make up substantial study data for research purposes in many fields. This problem is particularly pronounced in the social sciences. The YARG survey unfortunately falls into the category of what can be labeled, the college research sample problem; far to often sample for a variety of disciplines come from the college populations out of convenience (while there appears to be no "official" studies of this phenomena it seems likely to be an issue), as it takes data from college-aged people all over the world. There are several problems with mainly studying college-aged people and, inferring from their data, their insights about a topic. In the United States in particular white, affluent, people still make up most of the college age population on many campuses (Educationdata.org 2019). The crux of the college problem is that one 
is not sampling a diverse enough population to make transferrable conclusions about what is studied to the broader population, even if they are of the same age range. Far too many poor, racial minorities and other marginalized groups are often left out of studies conducted at college campuses. On top of the race issue is the age problem, what may be true for college-aged kids may hold quite different for middle-aged persons or seniors.

Moreover, the college research sample problem may unfortunately be more pronounced in some of the areas this study collected data than others. Of particular concern is the Israeli sample. YARG has two samples from Israel, one Hebrew, one Arabic. Judging from the decades of strife in Israel between the Jews and Palestinians, either sample may contain only the smartest, or financially well-endowed students. These young people, regardless, more than likely, do not represent most of the age cohort. The same issues of privilege and skewness are likely to be present in the Indian, Russian, and Peruvian samples. Because we were not supplied with the data concerning which schools these surveys were conducted at, for reasons of safety and confidentiality of the respondents, we have no actual way of knowing how the college research sample problem presents in these samples. All that aside, the survey more than likely yields a representation of religiosity and values of university students from a diverse set of countries.

This research may be limited in its ability to be generalizable, because the Portland State sample was so much larger than any of the others. Portland State's sample's N is 1996, while the next largest was Finland at $\mathrm{N}=484$, and the Indian Bengali sample was lowest with $\mathrm{N}=92$. The remaining samples are in the 100 to 300 range 
The second limitation of this research is its limited supply of variables to employ as controls. Most other studies of this type use the variables of race, an expanded gender category, what exact religion one practices, and marital status. The YARG study does not contain these variables, therefore my list of controls is somewhat short. Another limitation, as mentioned earlier in this thesis, is the college student sample problem. Even though the pool of respondents is quite varied from all over the world, the fact remains that they are likely to be upwardly class biased, although the sample at PSU is not. One final limitation are the nations or parts of the world that are left out. More nations in Africa such as South Africa, and nations in central and northern Africa, would make the sample more representative. Along with African nations, Australia and the Pacific islands region is also omitted. Finally, a few additional nations from Latin America would also make the sample more rounded out.

Accordingly, there are also limitations with comparing means of Schwartz values to gauge Individuality, Conservativism, and Cosmopolitanism-Humanitarianism. Firstly, there are inherent problems in comparing means to one another. Even if they are statistically significantly different, what does such a difference mean substantively? What does the difference of a half a point or a point mean regarding the Schwartz values that I have labeled as "Individual"? To be precise, as an example what does a score on Hedonism of six compared with four actually mean? What exact "units" of hedonism or stimulation are we measuring?

In sum, measuring values is always a tricky proposition, as their meaning can vary so much from person to person. However, I feel that Schwartz's Individual values come 
close to approximating young people's values. The questions that make up the scores for each value are worded carefully so as to assign a value correctly. On top of that the questions are also sufficiently randomized throughout the Schwartz battery and throughout the rest of YARG.

Implications

The implications of this thesis are threefold. First, the results from the regressions illustrate that young people can be secular, yet still moral, as the regression concerning volunteering indicates. Furthermore, the results also demonstrate how values differ from nation to nation, as in both Indian (One English speaking, one Bengali) and Israeli (One Hebrew, and presumably Jewish, and one likely Palestinian) samples. Lastly, this research points out that young people the world over exhibit values of Cosmopolitanism/ Humanitarianism.

Additionally, this research suggests a host of possible future research avenues. For instance, YARG contains a 15-item additive depression index. I conducted an examination demonstrating the higher the self-rated religion, the fewer depressive symptoms one had. I also conducted a linear regression showing a connection between religion and the status of being a foreign student.

Through a new and unique data set, this thesis has illuminated three aspects of young people's lives regarding rising secularity: religion, Cosmopolitanism/ Humanitarianism, and volunteering. In sum, young people have values of individuality, but seemingly within the confines of conservative values. Religiosity and the moral act of 
volunteering seem to have little to do with each other In other words, it appears that you do not have to be religious to have moral fiber, at least that which would prompt one to volunteer to help others. Lastly, I discovered that today's youths have values of cosmopolitanism. I highly suspect that this has a great deal to do with internet and or social media usage. Cosmopolitanism/Humanitarianism is important for many reasons in an everincreasingly globalized world. This thesis has barely scratched the surface of the wealth of information that lies within YARG's vast dataset. This survey can provide a snapshot of the religiosity, moral fiber, and personal values of this generation's college students. 


\section{References}

2020. "Shalom H. Schwartz - Google Scholar Citations." Retrieved June 4, 2019b (https://scholar.google.com/citations?user=7gi3pqoAAAAJ\&hl=en).

2018. "SAGE Reference - Maslow's Hierarchy of Basic Needs." Retrieved April 22, 2019a (http://sk.sagepub.com.proxy.lib.pdx.edu/reference/educationalpsychology/n166.xml).

Adorno. Theodore, Horkheimer, Max. 1982. The Dialectic of Enlightenment. New York. New York Theatre Communications Group. Print.

Alexandra Gheondea-Eladi. 2013. "Rational Choice Theory in Sociology: A Methodological Argument.” Revisal Română de Sociologie 24(3):337-347.

Anglim, Jeromy, Emily R. V. Knowles, Patrick D. Dunlop, and Andrew Marty. 2017. "HEXACO Personality and Schwartz's Personal Values: A Facet-Level Analysis." Journal of Research in Personality 68(C):23-31. doi: 10.1016/j.jrp.2017.04.002.

Baker, Joseph O. 2012. "Perceptions of Science and American Secularism." Sociological Perspectives 55(1):167-188. doi: 10.1525/sop.2012.55.1.167.

Baker, Joseph O. 2015. American Secularism: Cultural Contours of Nonreligious Belief Systems. New York: New York University Press.

Baudrillard, Jean. 1998. The Consumer Society: Myths and Structures. London: Sage Publications Ltd.

Beck, Ulrich. 2010. A God of One's Own: Religion's Capacity for Peace and Potential for Violence. English ed. Cambridge, UK; Malden, MA: Polity.

Block, Tina Marie. 2016. The Secular Northwest: Religion and Irreligion in Everyday Postwar Life. Vancouver, BC; Toronto: UBC Press.

Brandt, Allan M., and Paul Rozin. 1997. Morality and Health. Psychology Press.

Brown, Callum G. 2012. Religion and the Demographic Revolution: Women and Secularisation in Canada, Ireland, UK, and USA since the 1960s. Woodbridge: The Boydell Press.

Bruce, Steve. 2016. "The Sociology of Late Secularization: Social Divisions and Religiosity." The British Journal of Sociology 67(4):613-31. doi: 10.1111/1468-4446.12219.

Calhoun, Craig J. 2011. Rethinking Secularism. Oxford: University Press, USA.

Casanova, J. 2009. “The Secular and Secularisms.” Social Research 76(4):1049-1066.

Cieciuch, Jan, Shalom Schwartz, and Eldad Davidov. 2015. "The Social Psychology of Values." Pp. 41-46 in International Encyclopedia of the Social \& Behavioral Sciences.

Corbett, Michael. 2014. Politics and Religion in the United States. Second edition. New York: Routledge, Taylor \& Francis Group. 
Darwin, Charles. 1964. On the Origin of Species Through the Means of Natural Selection. Harvard College Press. Cambridge Mass.

Davie, Grace. 2007. The Sociology of Religion. London; Los Angeles: SAGE Publications.

Dobbelaere, Karel. 1999. "Towards an Integrated Perspective of the Processes Related to the Descriptive Concept of Secularization." Sociology of Religion 60(3):229-247. doi: $10.2307 / 3711935$.

Essen, Johan et al. 2014. Religion and Volunteering. Non-Profit Civil and Society Studies. Print.

Frykholm, Amy. 2008. "In the Non-Zone: Religion in the Pacific Northwest." The Christian Century, December 2, 22-.

Gauthier, François, and Hanna Lehtinen. 2013. "Religion, Neoliberalism and Consumer Culture." The Religious Studies Project. Retrieved August 17, 2019

(https://www.religiousstudiesproject.com/podcast/francois-gauthier-on-religionneoliberalism-and-consumer-culture/).

Gorski, Philip S., and Ateş Altinordu. 2008. “After Secularization?” Annual Review of Sociology 34:55-85.

Hagland, Kristen \& Fehring, Richard. 2009. " The Association of Religiosity, Sexual Education,

and Parental Factors with Risky Sexual Behaviors Among Adolescents and Young

Adults." Journal of Religion and Health. Issue 49.

Halsey, Philip. 1983. An Etmology of Latin and Greek. New Rochelle NY. A.D. Caratzas. Print.

Hammond, Phillip E. 1992. Religion and Personal Autonomy: The Third Disestablishment in America. Columbia, SC: University of South Carolina Press.

Hartman, Robert S. 2011. The Structure of Value: Foundations of Scientific Axiology. Wipf and Stock Publishers.

Iannaccone, Laurence R. 1995. "Voodoo Economics? Reviewing the Rational Choice Approach to Religion." Journal for the Scientific Study of Religion 34(1):76-88. doi:

$10.2307 / 1386524$.

Gallup. 2020." Religion" https://news.gallup.com/poll/1690/religion.aspx

Gallup. n.d. "U.S. Church Membership Down Sharply in Past Two Decades.” Gallup.Com. Retrieved May 27, 2019 (https://news.gallup.com/poll/248837/church-membershipdown-sharply-past-two-decades.aspx).

Ganga, N.S. and Kutty, Ramen. 2013. "Influence of religion, religiosity and spirituality on positive mental 
health of young people." Mental Health, Religion, and Culture. Volume 16. Issue 4.

IBM. 2020. "SPSS Replacing Missing Values."

IBM.https://www.ibm.com/downloads/cas/WOYGEMQO.

Inglehart, Ronald. 1977. The Silent Revolution: Changing Values and Political Styles among Western Publics. Princeton, New Jersey: Princeton University Press.

Inglehart, Ronald. 1981a. "Post-Materialism in an Environment of Insecurity." The American Political Science Review 75(4):880-900. doi: 10.2307/1962290.

Inglehart, Ronald. 1981b. "Post-Materialism in an Environment of Insecurity." The American Political Science Review 75(4):880-900. doi: 10.2307/1962290.

Inglehart, Ronald. 2018. Culture Shift in Advanced Industrial Society. Princeton University Press.

J., Musek. 1993. "The Universe of Human Values: A Structural and Developmental Hierachy." Studia Psychologica 35(4):321-26.

Jerf, W.K. et al. 2009. "Youth, Religiosity and Substance Abuse." Psychological Reports. Volume 105. Issue 1.

Johnson, Kathryn, et al. 2013. " Intrinsic Religiosity and Volunteering During Emerging Adulthood: A Comparison of Mormons with Catholics and Non-Catholic Christians."

Journal for the Scientific Study of Religion. Volume 52. Issue 4.

Johnston, Joseph. 2013. "Religion and Volunteering Over the Adult Life Course." Journal for the Scientific Study of Religion. Volume 52 Issue 4.

Killen, Patricia O'Connell, and Mark Silk. 2004. Religion and Public Life in the Pacific Northwest: The No Zone. Walnut Creek, CA: AltaMira Press.

Knoblauch, Hubert. 2011. "Deprivatization, the Public Sphere, and Popular Religion. (I: PORTRAIT: JOSE CASANOVA) (Essay).” 2:5.

Kosmin, Barry A. Barry Alexander. 2006. Religion in a Free Market: Religious and NonReligious Americans: Who, What, Why, Where. Ithaca, NY: Paramount Market Pub.

Mariano, R. 2008. "Uses and limits of the rational choice theory of religion." Tempo Social 20(2):41-66. doi: 10.1590/S0103-20702008000200003.

Maslow, Abraham. 1942. "A Theory of Human Motivation" British Journal of Psychiatry. Volume 208. Issue 4.

McLuhan, Marshall. 2013. Understanding Media: The Extensions of Man. Corte Madera, UNITED STATES: Gingko Press.

Meyer, Birgit March 21-, and Annelies Moors. 2006. Religion, Media, and the Public Sphere. Bloomington: Indiana University Press. 
Moscati, Arden \& Mezuk, Briana. 2014. "Losing Faith and Finding Religion." Drug and Alcohol

Dependence." Volume 136.

Norman, Richard. 2017. "Ethics and the Sacred: Can Secular Morality Dispense with Religious Values?” Analyse \& Kritik 39(1):5-24. doi: 10.1515/auk-2017-0001.

Paxton, Pamela et al. 2014. "Volunteering and Religions: A Cross National Analysis." Review of Religious

Research. Volume 56. Issue 4.

Pew. 2015. "Adults in Oregon - Religion in America: U.S. Religious Data, Demographics and Statistics.” Pew Research Center's Religion \& Public Life Project. Retrieved August 27, 2019 (https://www.pewforum.org/religious-landscape-study/).

Portland State University. 2018. "Facts: Portland State by the Numbers." Retrieved June 30, 2019.

https://www.pdx.edu/portland-state-university-facts.

Ray, Merrill, et al. 2001. " Relationship Between Family Religiosity and Drug use Behavior

Among Youth." Social Behavior and Personality. Volume 29. Issue 4.

Reitsma, Regan. 2004. "God, Our Commodity in Heaven: Rational Choice Theory and Religion." Christian Scholar's Review 33(2):213-236.

Robertson, David G., and Linda Woodhead. 2012. "Editors' Picks 4: The Secularisation Thesis." The Religious Studies Project. Retrieved August 8, 2019

(https://www.religiousstudiesproject.com/podcast/editors-picks-4-linda-woodhead-onthe-secularisation-thesis/).

Roccas, Sonia \& Sagiv, Lilach. 2017. Values and Behavior: Taking a Cross-Cultural Perspective. Springer International Publishing. Print

Rossi, Maurizio, and Ettore Scappini. 2014. "Church Attendance, Problems of Measurement, and Interpreting Indicators: A Study of Religious Practice in the United States, 1975-2010." Journal for the Scientific Study of Religion 53(2):249-267. doi: 10.1111/jssr.12115.

Saroglou, Vassilis, and Antonio Muñoz-García. 2008. "Individual Differences in Religion and Spirituality: An Issue of Personality Traits and/or Values." Journal for the Scientific Study of Religion 47(1):83-101. doi: 10.1111/j.1468-5906.2008.00393. x.

Saslow, Laura R., Robb Willer, Matthew Feinberg, Paul K. Piff, Katharine Clark, Dacher Keltner, and Sarina R. Saturn. 2013. "My Brother's Keeper? Compassion Predicts Generosity 
More Among Less Religious Individuals." Social Psychological and Personality Science 4(1):31-38. doi: 10.1177/1948550612444137.

Schwartz, Shalom H. 1992. "Universals in the Content and Structure of Values: Theoretical Advances and Empirical Tests in 20 Countries." Advances in Experimental Social Psychology 25(C):1-65. doi: 10.1016/S0065-2601(08)60281-6.

Schwartz, Shalom H., Jan Cieciuch, Michele Vecchione, Eldad Davidov, Ronald Fischer, Constanze Beierlein, Alice Ramos, Markku Verkasalo, Jan-Erik Lönnqvist, Kursad Demirutku, Ozlem Dirilen-Gumus, and Mark Konty. 2012. "Refining the Theory of Basic Individual Values." Journal of Personality and Social Psychology; Washington 103(4):663.

Simon, William E. 1970. "Self-Concept and the Validity of the Allport-Vernon-Lindzey Study of Values.” Perceptual and Motor Skills 31(1):263-266. doi: 10.2466/pms.1970.31.1.263.

Smith, Tom W. 1998. “A Review of Church Attendance Measures.” American Sociological Review 63(1):131-136.

Staff, Guardian. 2002. "We Are What We Buy, Says Sociologist.” The Guardian, December 19.

Thomas, Owen C. 2010. "The Atheist Surge: Faith in Science, Secularism, and Atheism." Theology and Science 8(2):195-210. doi: 10.1080/14746701003675561.

Turner. B.S. 2020. Cosmopolitanism and Religion. Brill Publishing The Netherlands. Print.

Vroman, Brian. 2013. "SAM HARRIS, THE MORAL LANDSCAPE, AND SOME UNANSWERED QUESTIONS.” 12(33):105-115. doi: 10.1017/S1477175612000267.

Wilcox, Rhonda V. 2011. "Diane Winston, Ed, Small Screen, Big Picture: Television and Lived Religion." Critical Studies in Television 6(1):140-.

Zimmer, Zachery et al. 2016. "Spirituality, religiosity, aging and health in global perspective: A review". Population Health. Volume 2. 


\section{Appendix A:}

\section{Refined Schwartz Values from Refined Theory}

Value Concept definition in terms of motivational goals

Self-direction-thought

Cultivate one's own ideas
Survey questions related to this value:

Being creative is important to them.

It is important to them to form their own opinions and have original ideas.

Learning things for themselves and improving their abilities is important to them

Self-direction-action Determine one's own actions

Survey questions related to this value:

It is important to them to make their own decisions about their life.

Doing everything independently is important to them.

Freedom to choose what one does is important to them

Stimulation Excitement, novelty, change

Survey questions related to this value:

They are always looking for different kinds of things to do.

Excitement in life is important to them

They think it is important to have all sorts of new experiences

Hedonism Pleasure and sensuous gratification

Survey questions related to this value:

Having a good time is important to them.

Enjoying life's pleasures is important to them.

They take advantage of every opportunity to have fun. 
Achievement

Success according to social standards

Survey questions related to this value:

They think it is important to be ambitious.

Being very successful is very important to them.

They want people to admire their achievements.

Power-dominance Power via exercising control over other people

Survey questions related to this value:

They want people to do what they say.

It is important to them to be the most influential person in any group.

It is important to them to be the one who tells others what to do.

Power-Resources Power via control of material and social resources

Survey questions related to this value:

Having the feeling of power that money can bring is important to them

Being wealthy is important to them.

They pursue high power and status.

Face

Maintaining one's public image and avoiding humiliation

Survey questions related to this value:

It is important to them that no one should ever shame them.

Protecting their public image is important to them.

They want people to treat them with respect and dignity.

Security personal Safety in immediate environment

Survey questions related to this value:

They avoid anything that might endanger their safety

Their personal security is extremely important to them.

It is important to them to live in secure surroundings. 
Tradition

Maintaining cultural, family, or religious traditions

Survey questions related to this value:

It is important to them that their country protect itself against all threats.

They want the estate to be strong so it can protect its citizens

Having order and stability in society is important to them.

Conformity-rules Compliance with rules or formal relations

Survey questions related to this value:

They believe they should always do what people in authority say

It is important to them to follow rules even when no one is watching

Obeying all laws in important to them.

Conformity-interpersonal Avoidance of upsetting or harming other people

Survey questions related to this value:

It is important to them to avoid upsetting other people.

They think it is important to never be annoying to anyone.

They always try to be tactful and avoid irritating other people.

Humility Recognizing one's insignificance in the larger scheme of things

Survey questions related to this value:

They try not to draw attention to themselves.

It is important to them to be humble.

It is important to them to be satisfied with what they have and not to ask for more.

Benevolence-dependability Being a reliable and trustworthy member of the ingroup

Survey questions related to this value:

It is important to them to be loyal to those close to them.

They go out of their way to be a loyal and trustworthy friend.

They want those who spend time with them to be able to rely on them completely. 
Benevolence-caring Devotion to wellbeing of ingroup members

Survey questions related to this value:

It is important to them to help the people dear to them.

Caring for the well-being of people they are close to is important to them.

They try always to be responsive to the needs of their family and friends.

Universalism-concern Commitment to equality, justice, and protection for all peoples

Survey questions related to this value:

Protecting society's week and vulnerable members is important to them. in life.

They think it is important that every person in the world have equal opportunities

They want everyone to be treated justly, even people they do not know.

Universalism-nature Preservation of the natural environment

Survey questions related to this value:

They strongly believe that they should care for nature.

It is important to them to work against threats to the world of nature.

Protecting the natural environment from destruction or pollution is important to them.

Universalism-tolerance Accepting differences of those who differ from oneself

Survey questions related to this value:

They work to promote harmony and peace among diverse groups.

It is important to them to listen to people who are different from him.

Even when he disagrees with people, it is important to understand them. 


\section{Appendix B: YARG Survey}

\section{YARG Final}

\section{Start of Block: Informed Consent}

\section{Consent_Desc1 Young adults and religion in a global perspective (YARG)}

\section{Welcome to the YARG survey and thank you for participating!}

We hope that you will enjoy answering the questions in this survey. They will provide an opportunity to reflect on things you might perhaps not talk about every day. Some questions relate to contentious issues or things you may take for granted. Please remember that this survey is being given in 13 different countries and to young adults with differing cultural backgrounds. We are interested in your perspective on these issues. You will notice that sometimes questions appear to repeat themselves or seem redundant. That is the way social scientists design surveys. Please be patient with this format. The results of this study will enhance our understanding of young adults today, but also of the culture you are part of.

Everyone who completes a survey will be entered into a lottery that will have two winners of $\$ 250$ each. After you have finished the survey you will see an option to volunteer to participate in Phase II of this study, which is an interview. Those who participate in a follow-up interview will be given a cash gift of $\$ 25.00$.

If you have any questions that have not been answered, or comments or complaints about your treatment in this study, please contact the principal investigator for the Portland State University component of this worldwide study:

Prof. Alex Stepick

Sociology Department

Office: Cramer Hall 217J

Portland State University

Box 751

Portland Oregon 97207

Stepick@pdx.edu

$503725-9843$

If you have questions regarding your rights as a research participant, you may call the PSU 
Office for Research Integrity (ORI) at (503) 725-2227 or 1(877) 480-4400. The ORI is the office that supports the PSU Institutional Review Board (IRB). The IRB is a group of people from PSU and the community who provide independent oversight of safety and ethical issues related to research involving human participants. For more information, you may also access the IRB website at https://sites.google.com/a/pdx.edu/research/integrity.

By filling in the survey form, starting on the link below, you consent to participate in the survey and agree with the following statements: I have been informed about the research project "Young adults and religion in a global perspective". I understand that the survey may be both interesting and thought provoking and that the results of this survey may be used in any way thought best for this study and published in academic reports, journals, and books. I understand and confirm that my participation in this survey is voluntary. If at any point in the survey if I feel discomfort or distress, I understand that I may choose not to participate without prejudice or penalty. I understand that there does exist a small risk of breach of confidentiality but that the researchers have taken every precaution to ensure that my confidentiality as a participant in this study will remain secure. My anonymity will be fully protected in relation to all parts of the research project. Researchers will not identify me by name in any reports or publications or by using information obtained from this survey.

Teachers, administrators, or anyone else on my campus, at my college or my university will not be informed about my participation or if I choose not to participate. They will not have access to any information or answers I have provided here. This precaution will prevent my individual comments from having any negative repercussions on me whatsoever.

If you agree to participate in this survey please click on the box "I agree to participate in this survey."

Clicking on this box indicates that you have read this letter informing you of the research project, its various stages, and your rights as a research participant. By clicking on the "I agree" box you agree to participate in this study, but you are not waiving any of your legal rights as a research participant. 


\section{PLEASE FEEL FREE TO PRINT THESE PAGES AND SAVE THEM FOR YOUR RECORDS}

I agree to participate in this survey (1)

I do not agree to participate in this survey (2)

\section{End of Block: Informed Consent}

Start of Block: A. Your current life situation

\section{$x \rightarrow x \rightarrow$}

A1

What is your marital status?

Single (1)

Married or in registered partnership (2)

Cohabitant or common-law marriage (3)

Widow/widower (4)

Divorced (5)

Separated (6)

A2 Do you have children (including adopted) or close relatives you are responsible for?

Yes (1)

No (2) 
A3 At the age of 15 , did you live in a city, suburb, or rural area?

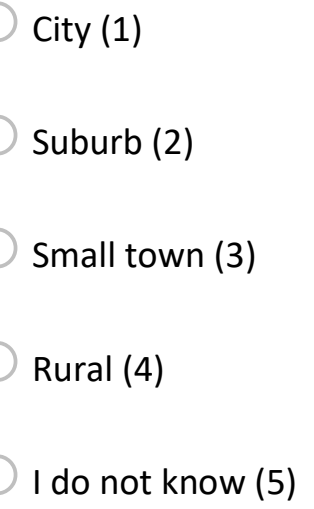


A4 Would you describe yourself as being a member of a group that is discriminated against in the U.S.? Please, select all that apply.
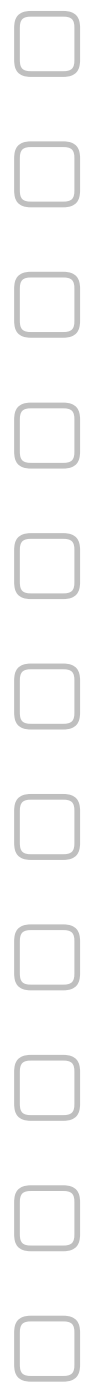

Other (11)

No, I do not feel discriminated against (0)

\section{Nationality (1)}

Religion (2)

Political orientation (3)

Language (4)

Ethnic group (5)

Age (6)

Gender (7)

Sexuality (8)

Disability (9)

Race (10) 
A5 In considering your family's monthly income relative to the average monthly income in the U.S., do you think yours is:

Much lower than the average (1)

Somewhat lower than the average (2)

About the average (3)

Somewhat higher than the average (4)

Much higher than the average (5)

I do not know (6)

A6 Tell us about your K-12 education, which of the following did you attend?

Public school (1)

Private school (2)

Home-schooled (3)

A combination, please specify (4)

Other, please specify (5) 
A7 Are you currently going to school full-time?

Yes (1)

No (2)

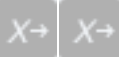

A8 Are you currently employed?

Yes (1)

No (2)

\section{$x \rightarrow x \rightarrow$}

A9 Are you receiving any financial aid or scholarship money for your studies?

Yes (1)

No (2) 
A10 Where do you currently live?

In a shared or non-shared, student accommodation, or a sub-let room (1)

With parents or other relatives (2)

In a privately rented apartment or house (3)

In an apartment or house owned by your parents, other relatives, or yourself (4)

Other, please specify (5)

\section{End of Block: A. Your current life situation}

\section{Start of Block: B. Your Social Life}

\section{$x \rightarrow x \rightarrow$}

B1 How often do you meet socially with friends or relatives?

$$
\text { Every day (8) }
$$

More than once a week (7)

Once a week (6)

At least once a month (5)

Only on special days or celebrations (4)

Less often (3)

Never (2)

I do not know (1) 
B2 Do you have anyone with whom you can discuss intimate and personal matters?

Yes (1)

No (2)

I do not know (3)

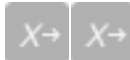

B3 Compared to other people of your age, how often would you say you take part in social activities?

Much less often (1)

Less often (2)

About the same (3)

More than most (4)

Much more than most (5)

I do not know (6) 
B4 Do you find doing things with other people difficult, even if you share interests and goals with them?

No $0(0)$
$1(1)$
$2(2)$
$3(3)$
$4(4)$
$5(5)$
$6(6)$
$7(7)$
$8(8)$
$9(9)$
$Y e s 10(10)$


B5, would you say that most people can be trusted, or that you cannot be too careful in dealing with people?

You cannot be too careful $0(0)$

$1(1)$

$2(2)$

$3(3)$

$4(4)$

$5(5)$

$6(6)$

$7(7)$

$8(8)$

$9(9)$

Most people can be trusted $10(10)$ 
B6 Do you feel safe walking alone at night in the city or area where you live?

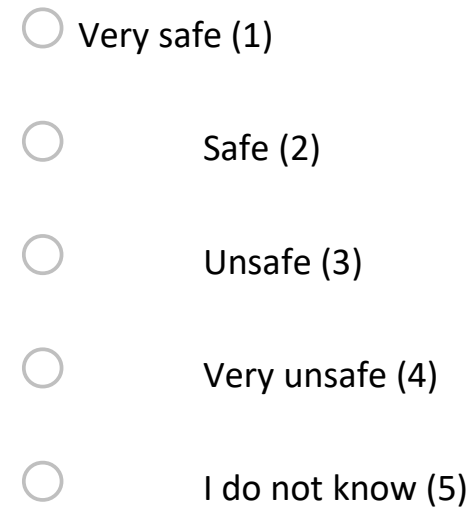

B7 In the past year, have you volunteered to help someone other than your family and close relatives, done something good for other people, or done some charity work?

Yes (1)

Probably yes (2)

Probably no (3)

No (4)

I do not know (5) 
B8 Do you consider yourself as belonging to one or more religious groups, communities, or traditions?

No (1)

Yes, which? (2)

\section{$x \rightarrow x \rightarrow$}

B9 Whether or not you belong to any, are there religious, spiritual, or philosophical communities, traditions or practices you feel close to or reflect your views?

\section{No (1)}

Yes, Please, describe (2) 
B10 Regardless of whether you consider yourself as belonging or close to a particular religious group, community, or tradition, how religious would you say you are?

Not at all religious $0(0)$

$1(1)$

$2(2)$

$3(3)$

$4(4)$

$5(5)$

$6(6)$

$7(7)$

$8(8)$

9 (9)

Religious 10 (10) 
B11 How religious would you say the family you grew up in was?

Not at all religious $0(0)$

$1(1)$

$2(2)$

$3(3)$

$4(4)$

$5(5)$

$6(6)$

$7(7)$

$8(8)$

$9(9)$

Deeply religious 10 (10) 
B12 About how often do you take part in religious ceremonies or services these days? Do not count special occasions such as weddings and funerals.

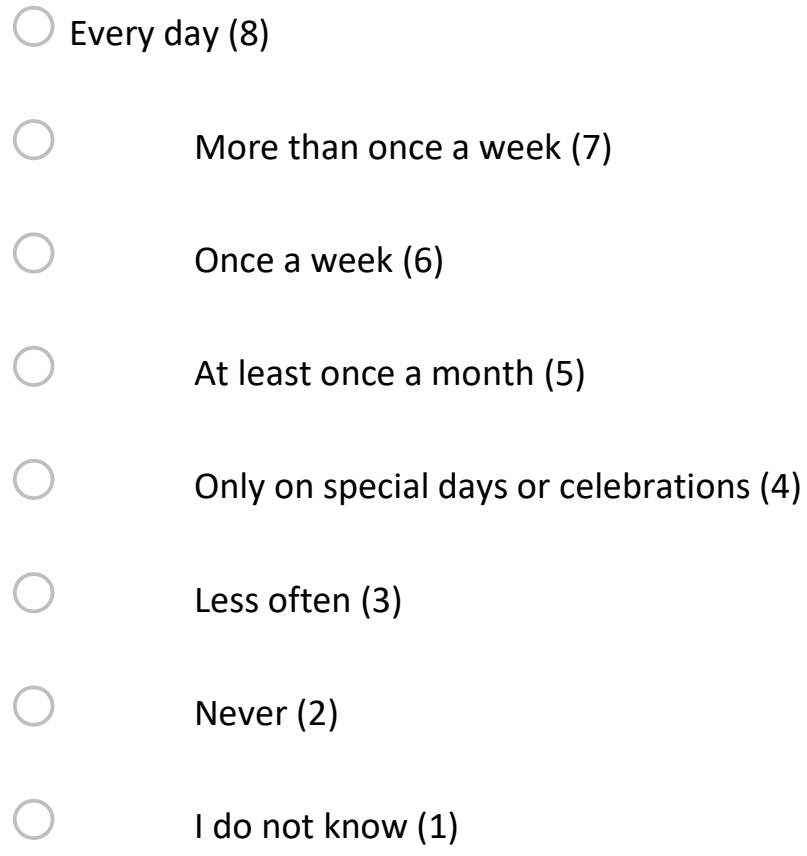


B13 Apart from when you are at religious ceremonies or services, how often do you engage in private religious or spiritual practices, such as worship, prayer, or meditation?

Every day (8)

More than once a week (7)

Once a week (6)

At least once a month (5)

Only on special days or celebrations (4)

Less often (3)

Never (2)

I do not know (1)

End of Block: B. Your Social Life

Start of Block: C. Your sources for news and information

$x \rightarrow x \rightarrow$ 
C1 In the past month, how frequently did you use the following media?

\begin{tabular}{c|ccccc} 
& $\begin{array}{c}\text { Every day } \\
(5)\end{array}$ & $\begin{array}{c}\text { Almost } \\
\text { every day } \\
(4)\end{array}$ & $\begin{array}{c}\text { Every } \\
\text { Week (3) }\end{array}$ & $\begin{array}{c}\text { Occasionally } \\
(2)\end{array}$ & Never (1) \\
\hline $\begin{array}{c}\text { Newspapers/magazines } \\
\text { (C1_1) }\end{array}$ & 0 & & & \\
Radio (C1_2) & & & & \\
Television (C1_3) & & & & \\
& & & & \\
Internet (C1_4) & & &
\end{tabular}


C2 For which of the following activities do you use the internet?

\begin{tabular}{|c|c|c|c|c|c|}
\hline & $\begin{array}{c}\text { Every day } \\
\text { (5) }\end{array}$ & $\begin{array}{c}\text { Almost } \\
\text { every day } \\
\text { (4) }\end{array}$ & $\begin{array}{c}\text { Every Week } \\
\text { (3) }\end{array}$ & $\begin{array}{c}\text { Occasionally } \\
\text { (2) }\end{array}$ & Never (1) \\
\hline $\begin{array}{l}\text { Communication, } \\
\text { e.g. email } \\
\text { (C2_1) }\end{array}$ & & & & & \\
\hline $\begin{array}{l}\text { Social media } \\
\qquad\left(\mathrm{C} 2 \_2\right)\end{array}$ & & & & & \\
\hline $\begin{array}{l}\text { Finding } \\
\text { information } \\
\text { (C2_3) }\end{array}$ & & & & & \\
\hline $\begin{array}{l}\text { Entertainment } \\
\qquad\left(\mathrm{C} 2 \_4\right)\end{array}$ & & & & & \\
\hline $\begin{array}{l}\text { Buying things or } \\
\text { services (C2_5) }\end{array}$ & ( & & & & \\
\hline $\begin{array}{l}\text { Selling things or } \\
\text { services (C2_6) }\end{array}$ & & & & & \\
\hline $\begin{array}{l}\text { Uploading self- } \\
\text { created content } \\
\text { (C2_7) }\end{array}$ & & & & & \\
\hline $\begin{array}{l}\text { Health or } \\
\text { wellbeing } \\
\text { related services } \\
\text { (C2_8) }\end{array}$ & & & & & \\
\hline $\begin{array}{l}\text { Religious or } \\
\text { spiritual } \\
\text { services and } \\
\text { issues (C2_9) }\end{array}$ & & & & & \\
\hline $\begin{array}{l}\text { Political issues } \\
\quad\left(C 2 \_10\right)\end{array}$ & $\bigcirc$ & 7 & $\bigcirc$ & & \\
\hline
\end{tabular}


C3 From where do you get information about news or current affairs? Please, select all that apply.

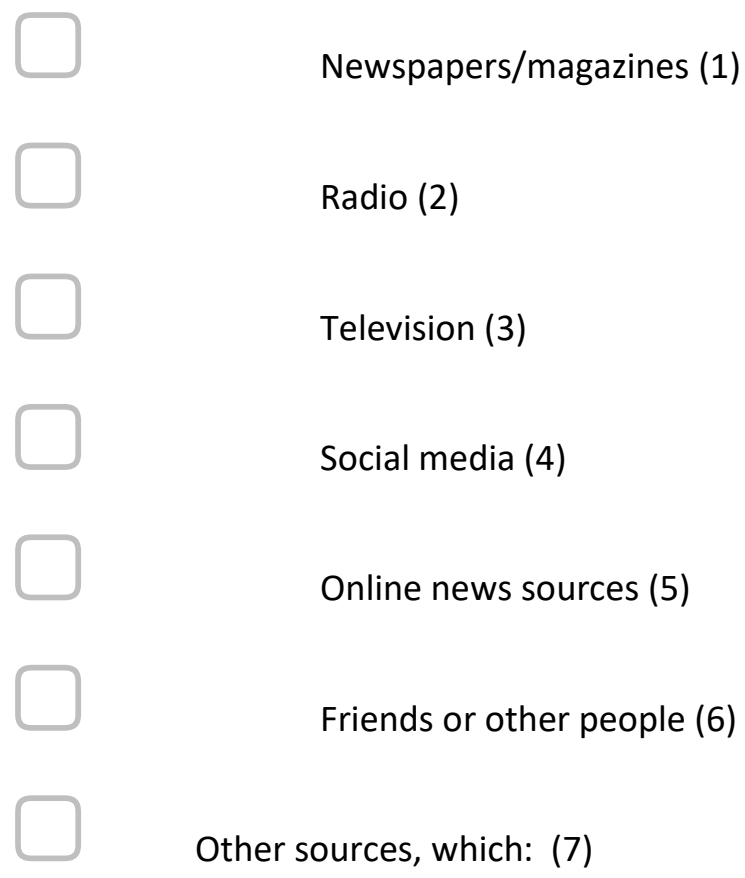

Other sources, which: (7) 
C4 Which of the following do you rely on for guidance as you live your life and make decisions? Please, select all that apply.

\section{Family (1)}

Trusted friends (2)

God or 'higher power' (3)

Past masters, saints, or teachers of my tradition (4)

Deceased loved ones (5)

Own intuition or feelings (6)

Own reason and judgement (7)

The teachings of my religion (8)

The religious or spiritual group to which I belong (9)

Local religious leaders (10)

National religious leaders (11)

The leader or leaders of my religious tradition (12)

Social media (13)

Science (14)

Great literature and art, past and present (15)

School or university teachers (16) 


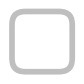

Government authorities (17)

Political party or politicians (18)

Some other, which: (19)

$\square$ None (20)

End of Block: C. Your sources for news and information

Start of Block: D. Your Views and Convictions

$x \rightarrow x \rightarrow$ 
D1 To what extent do you agree with the following statements? Please select all that apply. 


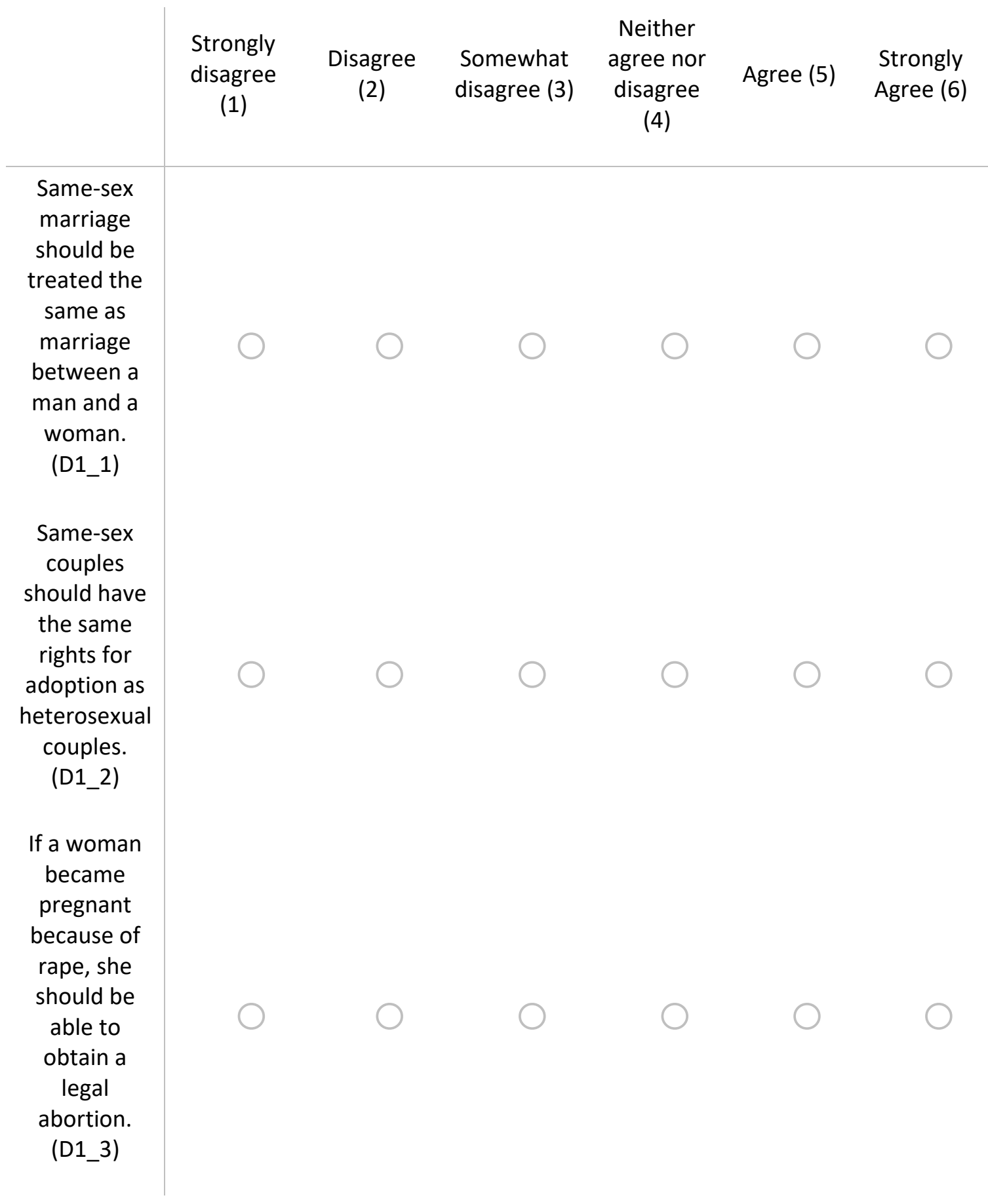




When a
woman's
own health
is seriously
endangered
by a
pregnancy,
she should
be able to
obtain a
legal
abortion.
(D1_4)
A pregnant
woman
should be
able to
obtain a
legal
abortion if
the woman
wants it for
any reason.
(D1_5)


D2 Consider a situation where a person is living in severe pain because of a disease that cannot be cured, and the person wants to die. To what extent do you agree with the following statements?

\begin{tabular}{|c|c|c|c|c|c|c|c|}
\hline & $\begin{array}{c}\text { Strongly } \\
\text { disagree } \\
\text { (5) }\end{array}$ & $\begin{array}{c}\text { Disagree } \\
\text { (4) }\end{array}$ & $\begin{array}{c}\text { Somewhat } \\
\text { disagree } \\
\text { (3) }\end{array}$ & $\begin{array}{c}\text { Neither } \\
\text { agree } \\
\text { nor } \\
\text { disagree } \\
(2)\end{array}$ & $\begin{array}{c}\text { Somewhat } \\
\text { agree (1) }\end{array}$ & $\begin{array}{c}\text { Agree } \\
(6)\end{array}$ & $\begin{array}{l}\text { Strongly } \\
\text { Agree (7) }\end{array}$ \\
\hline $\begin{array}{l}\text { Doctors } \\
\text { should } \\
\text { be } \\
\text { allowed } \\
\text { to end } \\
\text { the } \\
\text { patient's } \\
\text { life if the } \\
\text { patient } \\
\text { requests } \\
\text { it. (D2_1) }\end{array}$ & 0 & 0 & 0 & & & & $C$ \\
\hline $\begin{array}{l}\text { Doctors } \\
\text { should } \\
\text { be } \\
\text { allowed } \\
\text { to assist } \\
\text { the } \\
\text { patient } \\
\text { to } \\
\text { commit } \\
\text { suicide if } \\
\text { the } \\
\text { patient } \\
\text { requests } \\
\text { it. (D2_2) }\end{array}$ & 0 & 0 & 0 & & 0 & & \\
\hline
\end{tabular}


E1 All things considered, how satisfied are you with your life nowadays?

Extremely dissatisfied $0(0)$

1 (1)

$2(2)$

$3(3)$

$4(4)$

$5(5)$

$6(6)$

$7(7)$

$8(8)$

9 (9)

Extremely satisfied 10 (10) 
E2 Taking all things together, how happy would you say you are?

Extremely unhappy $0(0)$

$1(1)$

$2(2)$

$3(3)$

$4(4)$

$5(5)$

$6(6)$

7 (7)

8 (9)

9 (9)

Extremely happy 10 (10) 
E3 How satisfied are you with your present standard of living?

Extremely dissatisfied $0(0)$

$1(1)$

$2(2)$

$3(3)$

$4(4)$

$5(5)$

$6(6)$

$7(7)$

$8(8)$

9 (9)

Extremely satisfied $10(10)$ 
E4 How much do you agree or disagree with each of the following statements?

\begin{tabular}{|c|c|c|c|c|c|}
\hline & $\begin{array}{c}\text { strongly } \\
\text { disagree (1) }\end{array}$ & disagree (2) & $\begin{array}{c}\text { Somewhat } \\
\text { Disagree (3) }\end{array}$ & $\begin{array}{c}\text { Neither } \\
\text { agree to } \\
\text { disagree (4) }\end{array}$ & $\begin{array}{c}\text { Somewhat } \\
\text { agree (5) }\end{array}$ \\
\hline $\begin{array}{l}\text { I am always } \\
\text { optimistic } \\
\text { about my } \\
\text { future. } \\
\text { (E4_1) }\end{array}$ & & & & & \\
\hline $\begin{array}{c}\text { In general, I } \\
\text { feel } \\
\text { incredibly } \\
\text { positive } \\
\text { about myself } \\
\text { (E4_2) }\end{array}$ & & & & & \\
\hline $\begin{array}{l}\text { At times I } \\
\text { feel as if I am } \\
\text { a failure. } \\
\text { (E4_3) }\end{array}$ & & & & & \\
\hline $\begin{array}{l}\text { Overall, my } \\
\text { life is close to } \\
\text { how I would } \\
\text { like it to be. } \\
\text { (E4_4) }\end{array}$ & & & & & \\
\hline
\end{tabular}


E5 How much of the time during the past week have you... 


\begin{tabular}{|c|c|c|c|c|c|}
\hline & Not at all (1) & A little (2) & $\begin{array}{l}\text { A moderate } \\
\text { amount (3) }\end{array}$ & $A \operatorname{lot}(4)$ & $\begin{array}{c}\text { All the time } \\
\text { (5) }\end{array}$ \\
\hline $\begin{array}{c}\text { You felt } \\
\text { depressed? } \\
\text { (E5_1) }\end{array}$ & & & & & \\
\hline $\begin{array}{l}\text { You felt that } \\
\text { everything } \\
\text { you did was } \\
\text { an effort? } \\
\text { (E5_2) }\end{array}$ & & & & & \\
\hline $\begin{array}{c}\text { Your sleep } \\
\text { was restless? } \\
\text { (E5_3) }\end{array}$ & & & & & \\
\hline $\begin{array}{c}\text { You were } \\
\text { happy? (E5_4) }\end{array}$ & & & & & \\
\hline $\begin{array}{c}\text { You felt } \\
\text { Ionely? (E5_5) }\end{array}$ & & & & & \\
\hline $\begin{array}{l}\text { You enjoyed } \\
\text { life? (E5_6) }\end{array}$ & & & & & \\
\hline $\begin{array}{l}\text { You felt sad? } \\
\qquad(\text { E5_7) }\end{array}$ & & & & & \\
\hline $\begin{array}{l}\text { You could not } \\
\text { get going? } \\
\text { (E5_8) }\end{array}$ & & & & & \\
\hline $\begin{array}{l}\text { You had a lot } \\
\text { of energy? } \\
\text { (E5_9) }\end{array}$ & & & & & \\
\hline $\begin{array}{c}\text { You felt } \\
\text { anxious? } \\
\text { (E5_10) }\end{array}$ & & & & & \\
\hline $\begin{array}{l}\text { You felt tired? } \\
\qquad \text { (E5_11) }\end{array}$ & & & & & \\
\hline
\end{tabular}




You were
absorbed in
what you
were doing?
(E5_12)
You felt calm
and peaceful?
(E5_13)
You felt
bored?
(E5_14)
You felt really
rested when
you woke up
in the
morning?
(E5_15)

End of Block: E. Your Wellbeing and Happiness

Start of Block: F. Your personal details

F1 In which country where you born?

F2 What citizenship do you hold? 
F3 Are you in the U.S. on a student visa?

Yes (1)

No (2)

Other, please explain (3)

F4 In what year were you born?

\section{$x \rightarrow x \rightarrow$}

F5 What is your gender?

Male (1)

Female (2)

Nonbinary/third gender (3)

prefer to self-describe (4)

Prefer not to say (5)

Here we briefly describe different people. Please read each description and think about how much that person is or is not like you. Click on the circle to the right that shows how much the person described is like you. 
F6 How much is this person like you? 
Not like me at all

$2(2)$

$3(3)$

$4(4)$

Very much

1 (1)

1. It is

important to

them to form

their views

independently.

(Q44_1)

2. It is

important to them that

their country is

secure and

stable.

(Q44_2)

3. It is important to them to have a good time. (Q44_3)

4. It is important to them to avoid upsetting other people. (Q44_4)

5. It is important to them that the weak and vulnerable in society be protected. (Q44_5) 


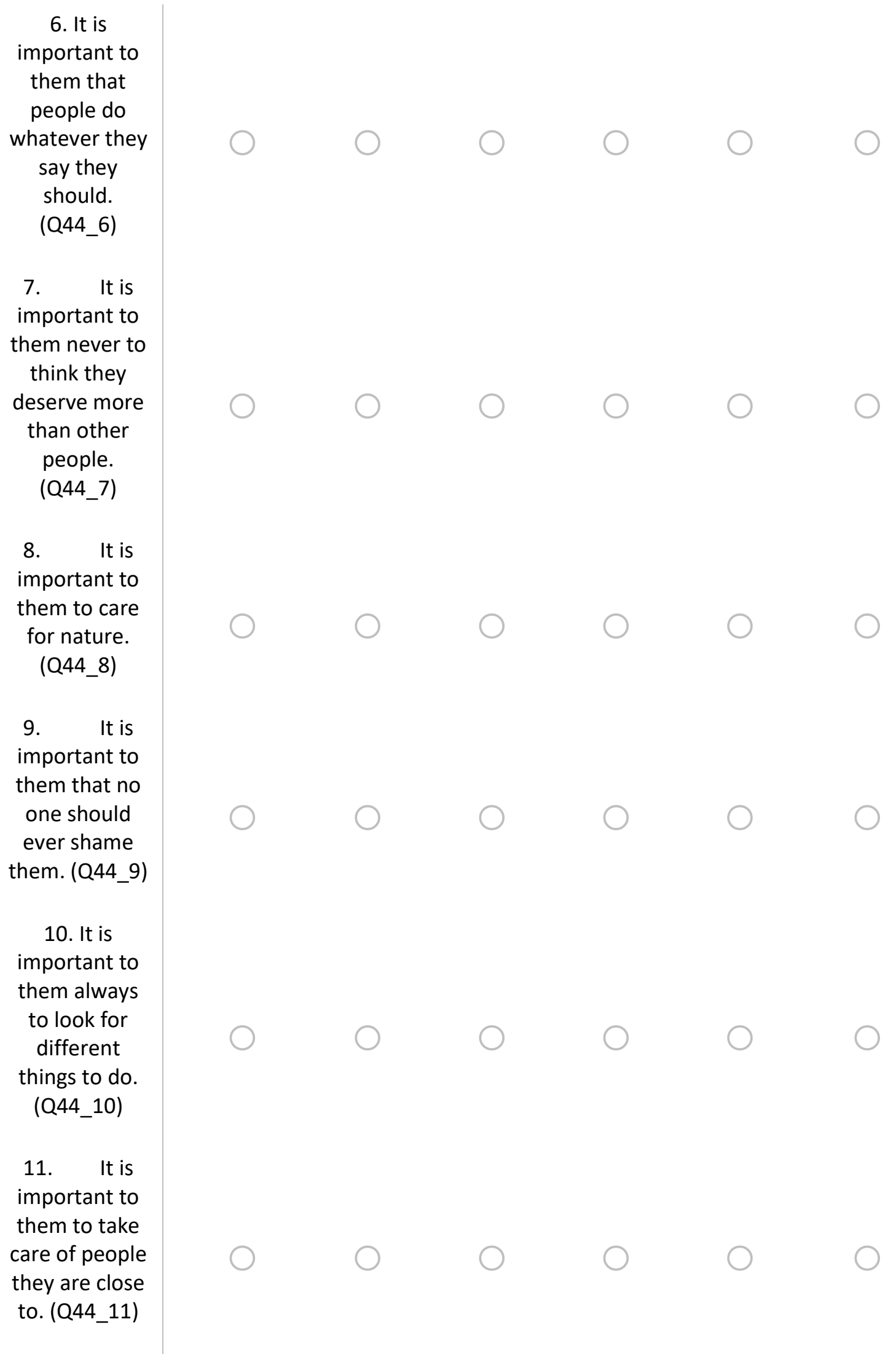


12. It is important to them to have the power that money can bring. (Q44_12)

13. It is important to them to avoid disease and protect their health.

(Q44_13)

14. It is important to them to be tolerant toward all kinds of people and groups. (Q44_14)

15. It is important to them never to violate rules or regulations. (Q44_15)

16. It is important to them to make their own decisions about their life. (Q44_16) 
17. It is important to them to have ambitions in life. (Q44_17)

18. It is important to them to maintain traditional values and ways of thinking. (Q44_18)

19. It is important to them that people they know have full confidence in themselves.

(Q44_19)

20. It is important to them to be wealthy. (Q44_20)

21. It is important to them to take part in activities to defend nature. (Q44_21)

22. It is important to them to never annoy anyone.

(Q44_22) 


\section{It is important to them to develop their own opinions. (Q44_23) \\ 24. It is important to them to protect their public image.} (Q44_24)

25. It is especially important to them to help the people dear to them. (Q44_25)

26. It is important to them to be personally safe and secure. (Q44_26)

27. It is important to them to be a dependable and trustworthy friend. (Q44_27)

28. It is important to them to take risks that make life exciting. (Q44_28) 


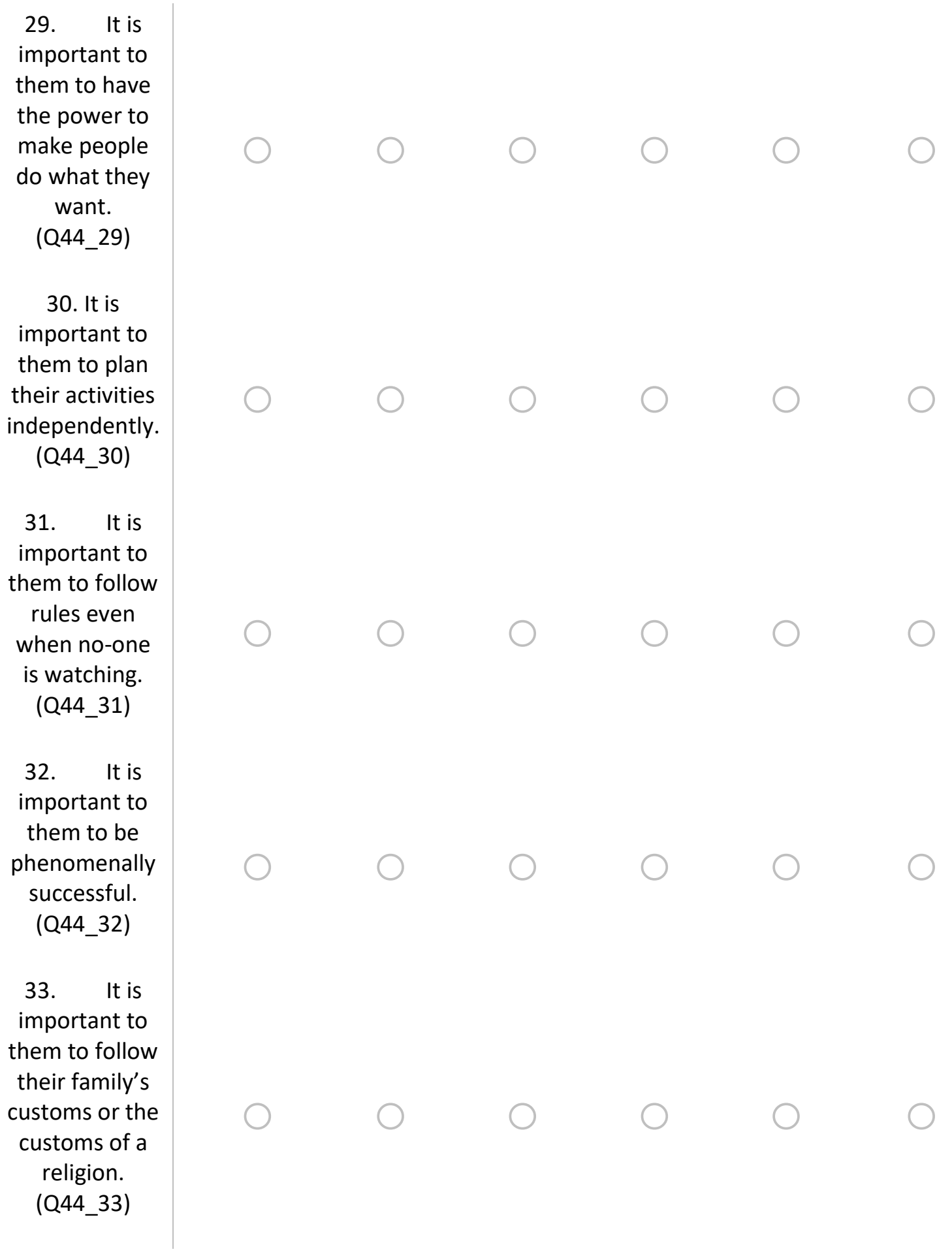




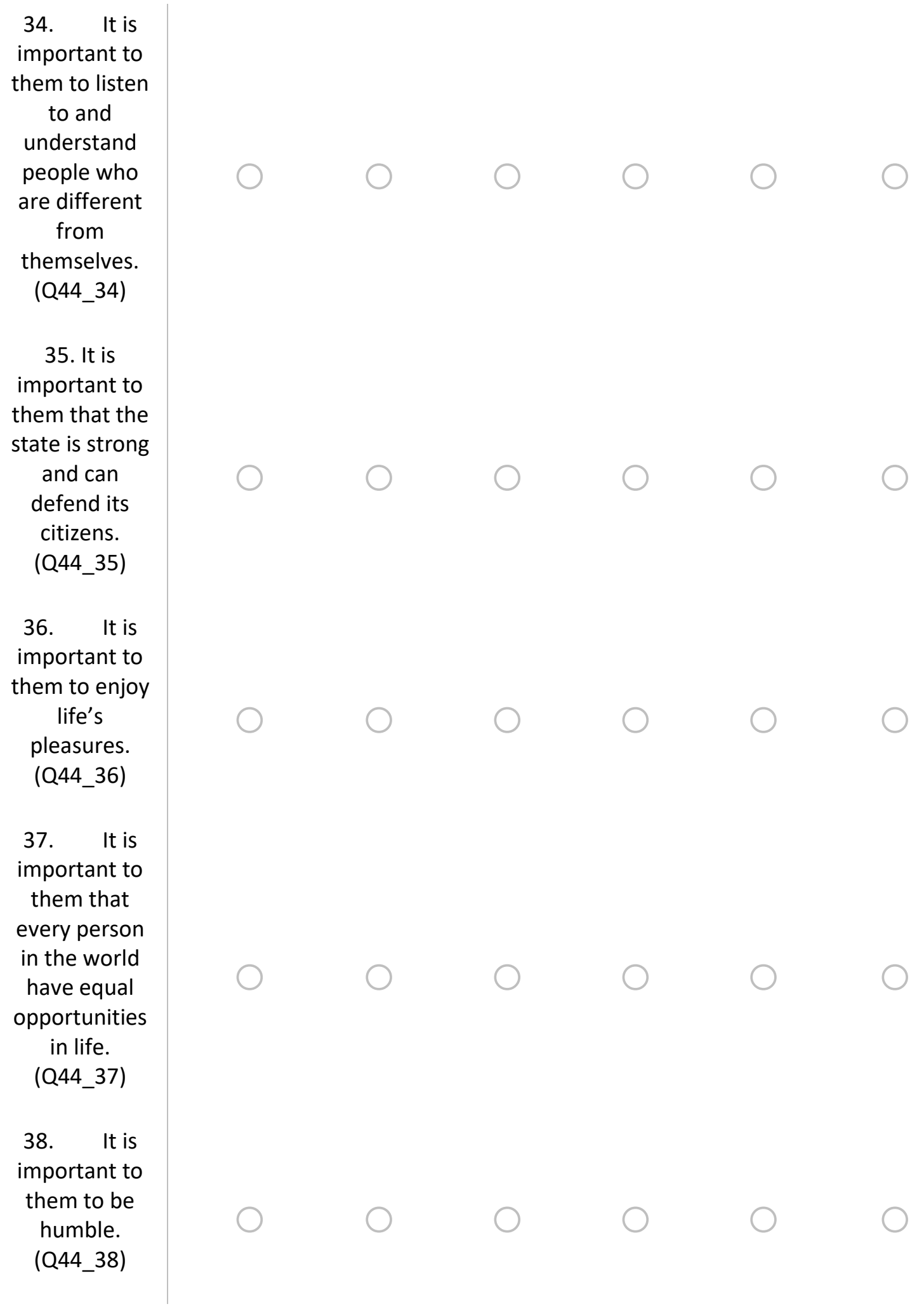


39. It is important to them to figure things out themselves. (Q44_39)

40. It is important to them to honor the traditional practices of their culture. (Q44_40)

41. It is important to them to be the one who tells others what to do. (Q44_41)

42. It is important to them to obey all the laws. (Q44_42)

43. It is important to them to have all sorts of new experiences. (Q44_43)

44. It is important to them to own expensive things that show their wealth. (Q44_44) 


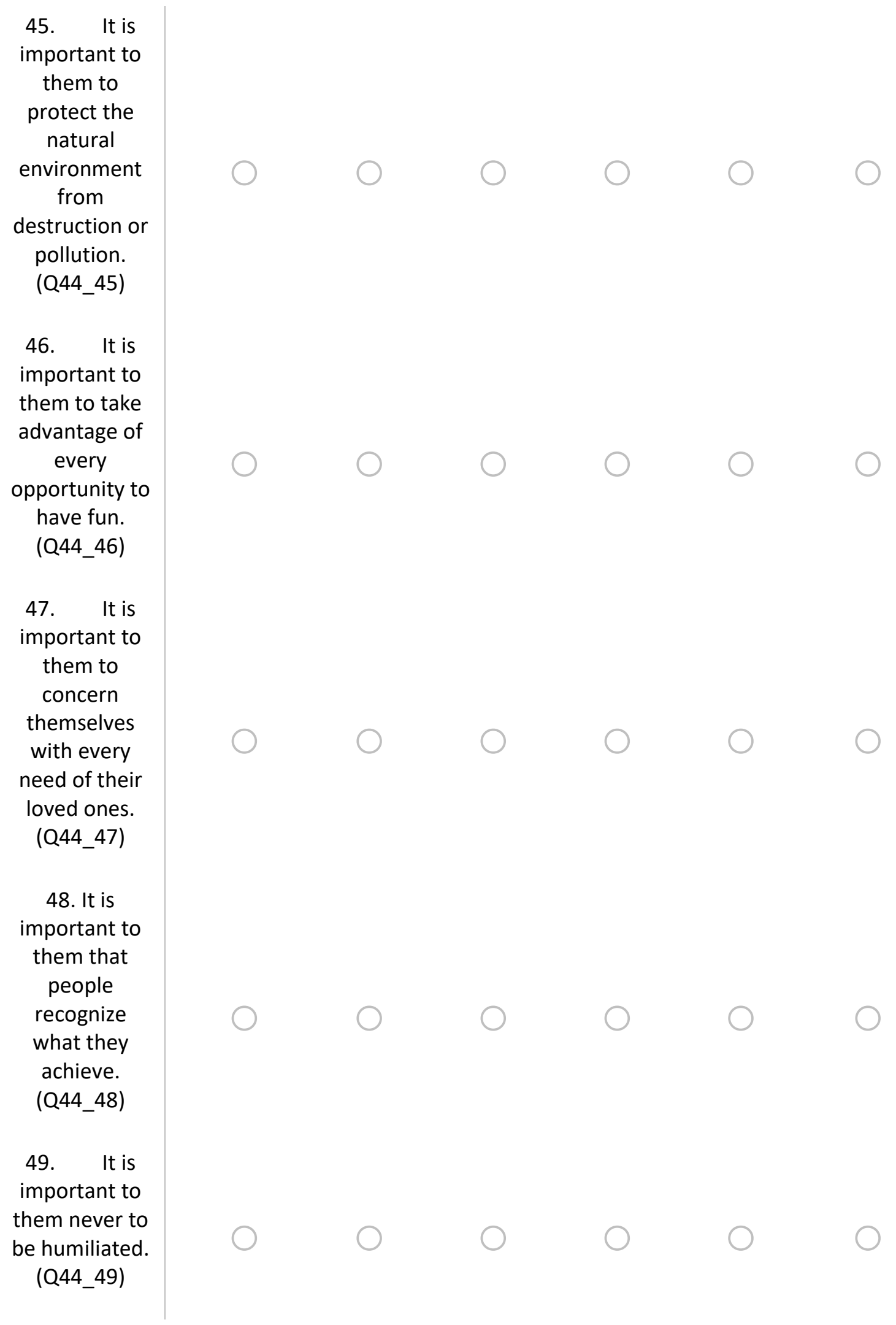




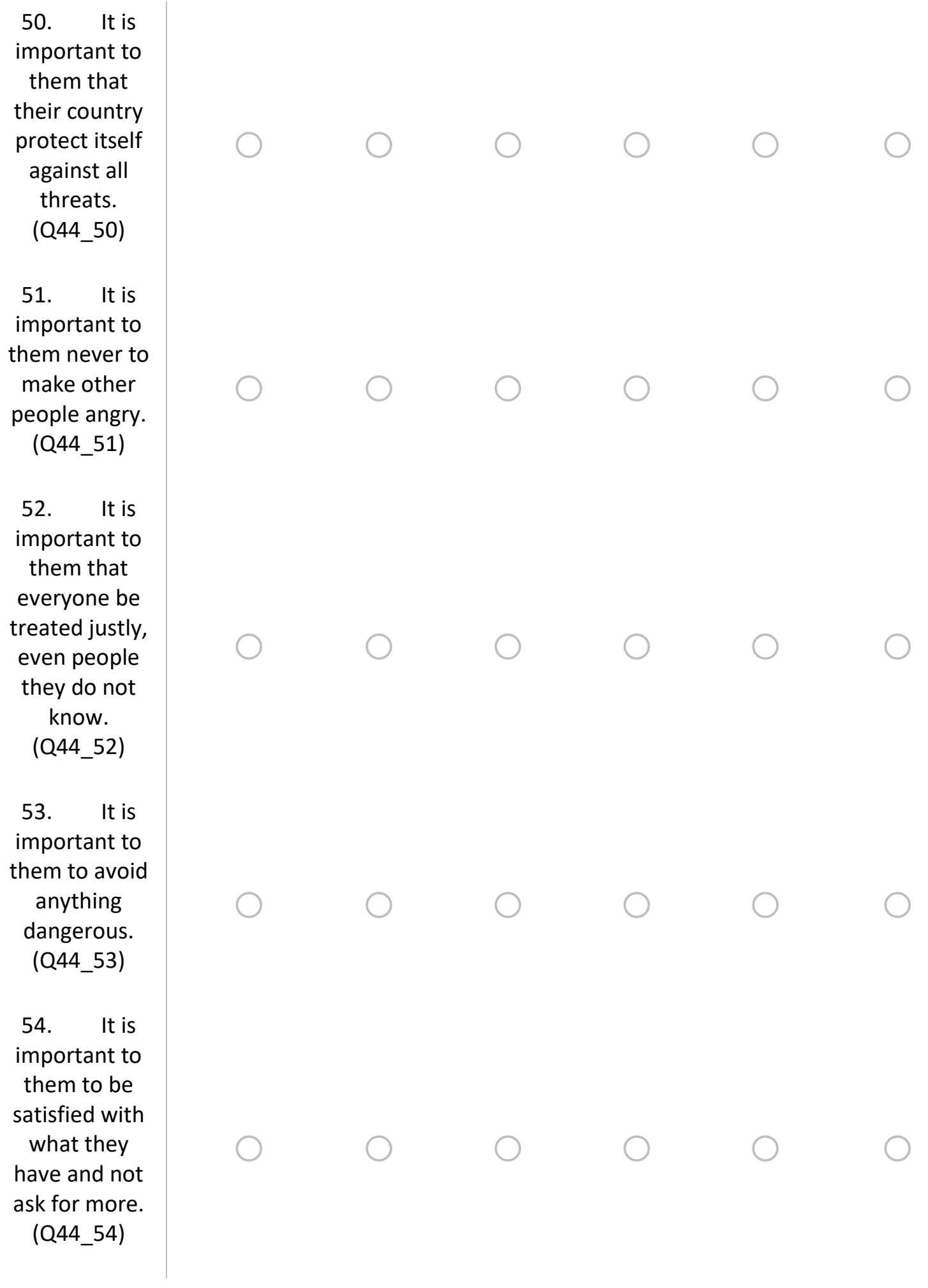




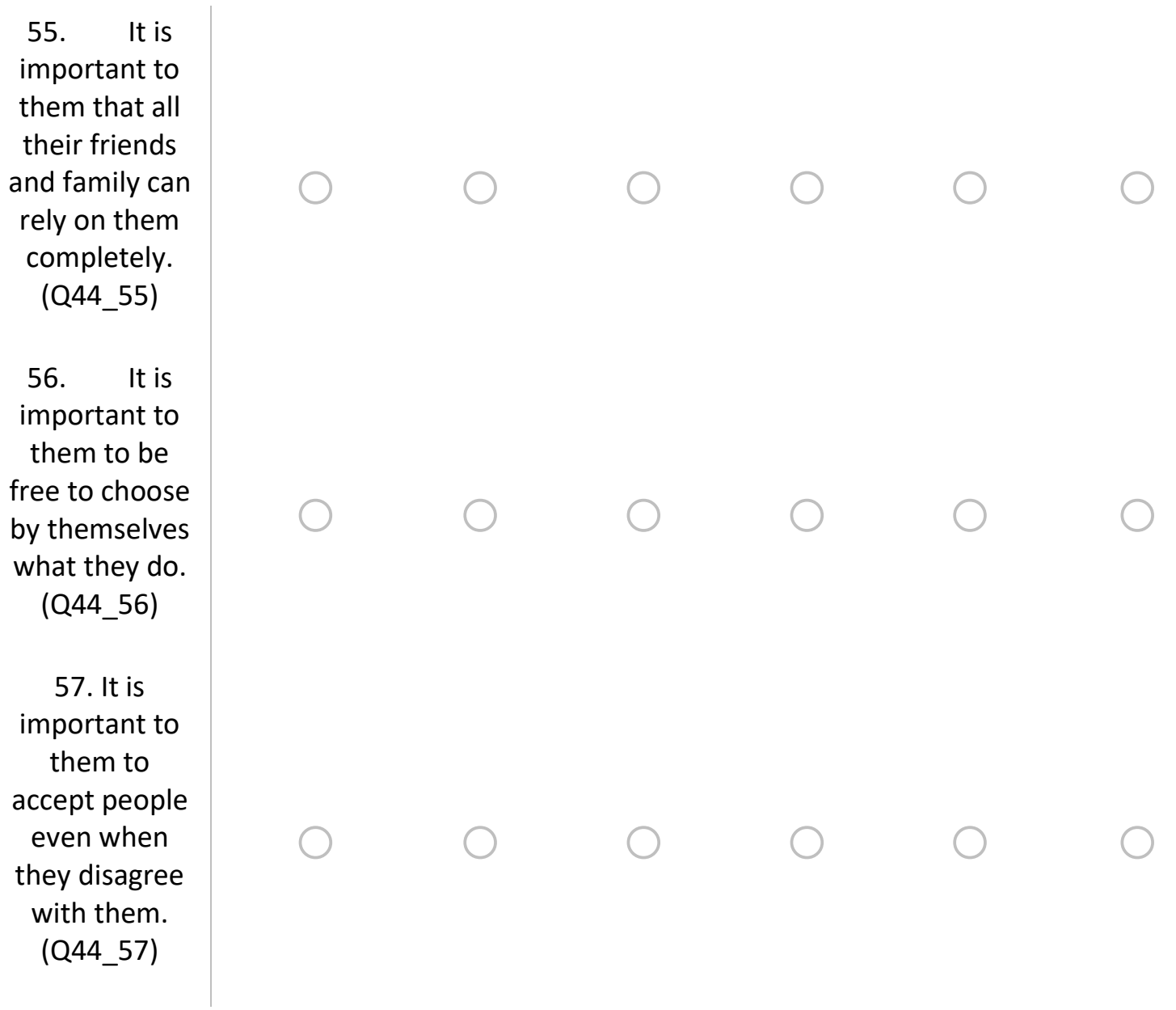

